\title{
CT Evaluation of Pediatric Supratentorial Tumors
}

\author{
Vinay Kumar D.P ${ }^{1}$, Akshatha M $^{2}$, Deb Kumar Boruah ${ }^{1}$, R.K . Gogoi ${ }^{1}$, \\ Skandesh B M ${ }^{1}$, Arjun Prakash ${ }^{1}$, Chiranjit Sarkar ${ }^{1}$. \\ 1. Department of Radiodiagnosis, Assam Medical College, Dibrugarh, India \\ 2. Department of Pediatrics, IGMC Shimla, India.
}

\section{Introduction}

Brain tumors are the most common solid tumor of childhood and the second most common malignancy after the leukemias. Primary central nervous system tumors (CNS) are the most common solid neoplasms in children. The incidence of CNS tumors is 2-5 new cases per 100000 per year, which is stable throughout the World. About $7 \%$ of the reported brain and CNS tumors occur in children aged $0-19$ years ${ }^{1,2}$

Although infratentorial tumors predominate in children, supratentorial tumors are more common in the first 2 to 3 years of life $^{2}$. The clinical manifestations in childhood with brain tumors are largely those of increased intracranial pressure. Headache is a common early symptom. Most other symptoms are non-specific and include vomiting, cranial neuropathies and stupor and coma in late stages. ${ }^{3}$

The largest percentage of childhood tumors $(17 \%)$ are located within the frontal, temporal, parietal and occipital lobes of the brain. For children aged 0-14 years, pilocytic astrocytomas, embryonal tumors, and malignant glioma are the common tumors. The most common histologies in adolescent ages 15 - 19 years include tumors of the pituitary and pilocytic astrocytoma. ${ }^{1}$

Supratentorial intraaxial tumors are not very common in children but they are histologically more varied than in adults. Although there have been several neuroradiological investigations, accurate diagnosis by imaging modalities alone remains difficult in all cases, and final diagnosis in most cases requires histological examination. However, neuroradiological information is valuable in predicting tissue character and histological type or grade, and in helping establish treatment strategies. ${ }^{4,5}$

The imaging modalities used are mainly CT and MR imaging with newer modalities like MR and CT perfusion, PET and SPECT.

CT has become the primary imaging investigation in cases of suspected brain tumors, surpassing many other invasive imaging modalities. It has considerably high sensitivity, it is non-invasive having no hazards except ionizing radiations. CT can predict the pathological nature of a lesion with reasonable degree of accuracy. CT scan is more accurate indicator of brain tumor, yet it is not always $100 \%$ accurate. $^{6}$

MRI has its advantage of being a radiation free and multi-planar imaging facility. Hence a lesion can be seen in three planes and accurate localization of the lesion can be done. This modality provides better soft tissue characterization and can clearly demonstrate peritumoral edema, but has disadvantages like high cost , requires a long time for acquisition of the data and hence cannot be used for restless patient particularly neonates, infants or even uncooperative children. It cannot be done in patients having metallic implants for which CT is the modality of choice. ${ }^{3}$

Newer multi-slice helical CT scanners are capable of providing highly collimated sub millimeter thickness sectional images in extremely short acquisition times and thus areas of hyperostosis or bone destruction, intratumoral calcification and early intratumoral or peritumoral hemorrhage are more completely defined with greater certainty on CT than on $\mathrm{MRI}^{3}$

\section{Objectives of the Study}

1. To study the distribution of various supratentorial neoplasms in pediatric age group.

2. To study the CT features of supratentorial neoplasms in pediatric age group.

3. To localise and assess the extent of supratentorial neoplasms in pediatric age group.

\section{Materials and Methods}

This study of "CT EVALUATION OF SUPRATENTORIAL TUMORS IN PEDIATRIC AGE GROUP" was conducted on 36 patients at Assam Medical College \& Hospital, Dibrugarh, with a suspicion of intracranial SOL by neurologists, pediatricians and physicians from in and around Dibrugarh over a period of three year from July 2011 to June 2014.

Methodology: This was a study done to evaluate the efficacy of computed tomography in the diagnosis of supratentorial tumors in pediatric age group.

Place of study: Department of Radiology, AMCH, Dibrugarh. 
Duration of study: 3 years

Study group and Inclusion criteria:

The study comprised of patients less than $(<$ or $=$ to 18 years) 18 years presenting to the department of radiodiagnosis after suspected to have brain tumors by pediatricians, neurologists and physicians, were taken up for radiological evaluation by CT scan.

\section{Criteria for exclusion:}

All cases with supratentorial pathology and symptomatology due to infections, congenital malformations, trauma or cerebrovascular accidents etiology were excluded.

\section{Study protocol:}

The scheme started with patient's serial number, name, age, sex, address, hospital / MRD number, date of admission and examination. A thorough case history preceeded the clinical examination viz symptoms, duration of symptoms, type of onset with past and family history. The history was obtained from patients, eye witnesses as well as close family members.

Infants and children who were not co-operative were sedated by giving oral /IV sedatives.

Consent of the patient and attendant was taken for the contrast examination. The procedure and objective of performing examination was explained to the patients.

\section{CT PROTOCOL :}

All CT scans were performed using SIEMENS SOMATOM SPIRIT DUAL SLICE Computed Tomography system.

\section{Scanning technique:}

The examination by CT scan was tailored to the clinical problem at hand. Initially after positioning of the patient, a topogram was taken.

Routine axial scans will be performed in all cases, taking orbito-meatal plane as the baseline both prior to and after administration of non-ionic contrast, which were done with the consent of the patient. Scanning parameters used were $5 \mathrm{~mm}$ slice thickness with $5 \mathrm{~mm}$ table increment routinely. Thin contiguous slices of 2 $\mathrm{mm}$ or $3 \mathrm{~mm}$ were done whenever necessary. $\mathrm{kVp}$ and $\mathrm{mAs}$ were tuned to match age specific pediatric brain protocol.

Multiple coronal and sagittal reformatted images were frequently used to further analyse the lesions detected on axial scans. the tumors.

The pre and post contrast attenuation values, size and location of lesions were reviewed to characterise

All cases were followed up either with other imaging modalities like MRI/ PET and clinically correlated to confirm the diagnosis given on CT scan, either by the characteristic imaging features or post operative histopathological reports, wherever possible. Details of the treatment and the procedure done on patients studied on outpatient/ referral basis were obtained from the referring consultants and recorded.

Intraaxial -25

\section{Results and Observations}

Extraaxial- 11

The ratio of intra-axial to extra-axial tumors was 2.27.

Supratentorial Tumors (Intraxial tumors)

Table-5.1. Astrocytomas (Number of Cases 12)

\begin{tabular}{||l||l||c|c||c||c||}
\hline \hline \multirow{3}{*}{ TUMOR } & $\begin{array}{c}\text { NUMBER OF } \\
\text { CASES }\end{array}$ & $\begin{array}{c}\text { \% OUT OF INTRA } \\
\text { AXIAL }\end{array}$ & $\begin{array}{c}\text { \% OUT OF } \\
\text { SUPRATENTORIAL }\end{array}$ & $\begin{array}{c}\text { \% OUT OF } \\
\text { ASTRO) }\end{array}$ \\
\hline \hline \multirow{5}{*}{ LGA } & Pilocytic astro & 3 & 12.00 & 8.33 & 25.00 \\
\cline { 2 - 6 } & Diffuse LGA & 2 & 8.00 & 5.55 & 16.66 \\
\cline { 2 - 6 } & SEGCA & 1 & 4.00 & 2.77 & 8.33 \\
\cline { 2 - 6 } & Optic N Glio & 2 & 8.00 & 5.55 & 16.66 \\
\cline { 2 - 6 } & Total & 8 & 32.00 & 22.25 & 66.66 \\
\hline \multirow{3}{*}{ HGA } & Anaplastic astro & 2 & 8.00 & 5.55 & 16.66 \\
\cline { 2 - 6 } & GBM & 2 & 8.00 & 5.55 & 16.66 \\
\cline { 2 - 5 } & Total & 4 & 16.00 & 11.10 & 33.33 \\
\hline
\end{tabular}


Low grade astrocytomas accounting for $22.20 \%$ ( 8 cases) of all pediatric supratentorial tumors were the single largest group in our study, whereas high grade gliomas accounted for $11.10 \%$ ( 4 cases). Out of all astrocytomas, pilocytic astroytoma was the commonest accounting for $25 \%$ ( 3 cases). Among high grade astrocytomas, $50 \%$ were anaplastic type and the rest $50 \%$ were of GBM type.

Table -5.2

Neuronal and Mixed Neuronal Glial tumors (No. of Cases 4)

\begin{tabular}{|l||c||c||r||}
\hline \hline Tumor & $\begin{array}{c}\text { NUMBER OF } \\
\text { CASES }\end{array}$ & $\begin{array}{c}\text { \%UT OF INTRA OUT OF } \\
\text { AXIAL }\end{array}$ & $\begin{array}{c}\text { \% OPRATENTORIAL } \\
\text { SUlioma }\end{array}$ \\
\hline \hline Ganglioglioma & 1 & 4.00 & 2.77 \\
\hline \hline DIG & 2 & 8.00 & 5.55 \\
\hline \hline Central neurocytoma & 1 & 4.00 & 11.11 \\
\hline \hline Total(NMNG) & 4 & 16.00 & 2.77 \\
\hline
\end{tabular}

In our study, 4 cases were neuronal and mixed neuronal glial tumors which included 2 cases of DIG, 1 case each of Ganglioglioma and central neurocytoma. As a group, NMNGs were the third most common intraaxial tumors in our study accounting for $11.11 \%$ of all Supratentorial tumors.

Table -5.3

OTHER INTRAAXIAL TUMORS. (9 cases)

\begin{tabular}{||l||c||c||c||}
\hline \hline Tumor & $\begin{array}{c}\text { NUMBER OF } \\
\text { CASES }\end{array}$ & $\begin{array}{c}\text { \% OUT OF } \\
\text { INTRA AXIAL }\end{array}$ & $\begin{array}{c}\text { \% OUT OF } \\
\text { SUPRATENTORIAL }\end{array}$ \\
\hline \hline PNET & 5 & 20.00 & 13.80 \\
\hline \hline Oligodendroglioma & 2 & 8.00 & 5.55 \\
\hline \hline Ependymoma & 2 & 8.00 & 5.55 \\
\hline
\end{tabular}

Among other Supratentorial lesions, PNET was the commonest accounting for $13.8 \%$ (5 cases). Among intraaxial lesions, PNET was the second most common after low grade astrocytomas accounting for $20 \%$ of intraaxial tumors, with ependymomas and oligodendrogliomas accounting for $8 \%$ each.

\section{Table-5.4}

SEX DISTRIBUTION IN INTRAAXIAL LESIONS (25 CASES)

\begin{tabular}{||c||c||c||}
\hline SEX & $\begin{array}{c}\text { NUMBER } \\
(\mathrm{n})\end{array}$ & PERCENTAGE (\%) \\
\hline \hline Male & 14 & 56.00 \\
Female & 11 & 44.00 \\
\hline \hline TOTAL & 25 & 100.00 \\
\hline
\end{tabular}

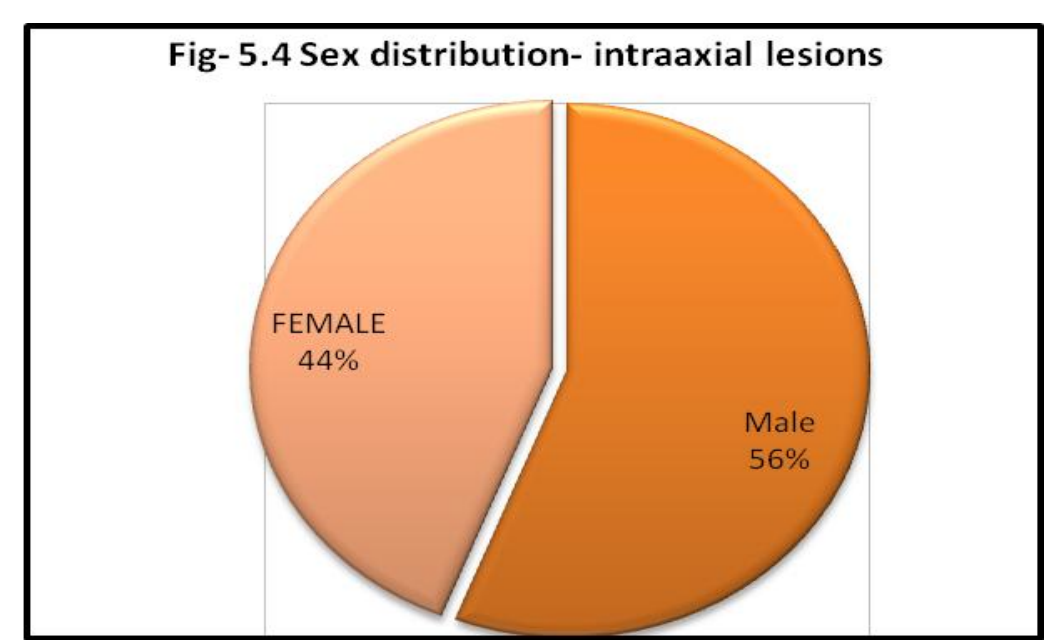

The male: female ratio amongst intraaxial lesions was 1.27:1. 
Table-5.5

Age Distribution: Number of cases $=25$

\begin{tabular}{|c||c||c||c||c||c||c||c||}
\hline AGE(years) & LGA & HGA & NMNG & PNET & OLIGO & EPEND & $\begin{array}{c}\text { TOTAL } \\
\text { n(\%) }\end{array}$ \\
\hline \hline$<1$ & 0 & 0 & 2 & 0 & 0 & 0 & $2(8)$ \\
\hline \hline 1 to 5 & 0 & 0 & 0 & 2 & 0 & 0 & $2(8)$ \\
\hline \hline 6 to 10 & 4 & 1 & 0 & 3 & 0 & 0 & $8(32)$ \\
\hline \hline 11 to15 & 1 & 1 & 1 & 0 & 1 & 0 & $4(16)$ \\
\hline 16 to18 & 3 & 2 & 1 & 0 & 1 & 2 & $9(36)$ \\
\hline
\end{tabular}

16-18 years was the predominant age group amongst intraaxial tumors accounting for $36 \%$ of intraaxial tumors, but low grade astrocytomas and PNET were predominantly seen in the age group of 6-10 years.

Table-5.6

Symptoms: Number of cases-25

\begin{tabular}{|c|c|c|c|c|c|c|c|}
\hline SYMPTOM & LGA & HGA & NMNG & $\begin{array}{l}\text { PNET } \\
\end{array}$ & OLIGO & EPEND & $\begin{array}{c}\text { TOTAL } \\
\mathrm{n}(\%)\end{array}$ \\
\hline Headache & 2 & 0 & 0 & 0 & 0 & 0 & $2(8)$ \\
\hline Seizures & 2 & 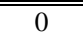 & $\overline{11}$ & 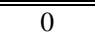 & 2 & 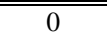 & $\bar{~} 5(20)$ \\
\hline Dim vision & 2 & 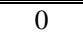 & 0 & 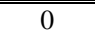 & 0 & 0 & $2(8)$ \\
\hline Raised ICT & 1 & 3 & 3 & 3 & 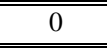 & 2 & 12(48) \\
\hline others & 1 & 1 & 0 & 2 & 0 & 0 & $4(16)$ \\
\hline
\end{tabular}

Raised ICT was the most common symptom in our study seen in 12 cases (48\%) amongst supratentorial intraaxial lesions, especially in high grade astrocytomas (75\%), NMNGs (75\%), PNET (60\%) and Ependymoma (100\%).

Table -5.7.

Location of intraaxial lesions

\begin{tabular}{||l||c||c||c||c||c||l||c||}
\hline \hline & & LGA & HGA & NMNG & PNET & OLIGO & EPEND \\
\hline Hemispheric & $<1$ lobe & 3 & 1 & 1 & 2 & 2 & 0 \\
\cline { 2 - 9 } & $>1$ lobe & 0 & 1 & 2 & 3 & 0 & 0 \\
\hline \hline Basal ganglia & & 1 & 1 & 0 & 0 & 0 & 0 \\
\hline \hline Periventricular & & 2 & 1 & 1 & 0 & 0 & 2 \\
\hline Optic chiasm & & 2 & 0 & 0 & 0 & 0 & 0 \\
\hline
\end{tabular}

Supratentorial PNETs were large hemispheric lesions which were distributed in more than one lobe in $60 \%$ (3 cases) and similar distribution was seen in 50\% of NMNGs and 25\% of high grade astrocytomas. Ependymomas showed periventricular distribution in our study.

Table -5.8 . Pre Contrast features of intraaxial lesions

\begin{tabular}{|c|c|c|c|c|c|c|}
\hline $\begin{array}{c}\text { Features } \\
\text { (pre-contrast) }\end{array}$ & LGA & HGA & NMNG & PNET & OLIGO & EPEND \\
\hline Hyperdense & 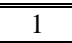 & $\overline{11}$ & 2 & $\overline{5}$ & 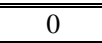 & $\overline{0}$ \\
\hline Isodense & 2 & 2 & 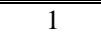 & 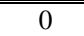 & 1 & 11 \\
\hline Hypodense & 5 & 1 & 1 & 0 & 1 & 1 \\
\hline Calcifications & 2 & 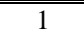 & 2 & $\overline{25}$ & 2 & 2 \\
\hline Multiplicity & 0 & 0 & 0 & 0 & 1 & 0 \\
\hline
\end{tabular}

On NECT, $62.5 \%$ (5 cases) were hypodense among low grade astrocytomas, whereas $100 \%(5$ cases) of PNET were hyperdense in attenuation in our study. In both oligodendrogliomas and Ependymoma, 50\% of the cases were hypodense and the rest $50 \%$ were isodense on NECT.

$100 \%$ of cases amongst PNET, oligodendrogliomas and ependymoma showed intralesional calcifications in our study. Calcification was seen in $25 \%$ of low grade astrocytomas and $25 \%$ of high grade astrocytomas. 
Table 5.9- Secondary effects by intraaxial tumors (in \%)

\begin{tabular}{|l||c||c||c||c||c||c||}
\hline \hline $\begin{array}{l}\text { Secondary } \\
\text { Effects }\end{array}$ & LGA & HGA & NMNG & PNET & OLIGO & EPEND \\
\hline \hline PLE & 37.50 & 100 & 50 & 80 & 0 & 100 \\
\hline \hline Mass effect & 37.50 & 100 & 50 & 80 & 0 & 100 \\
\hline \hline Hydrocephalus & 12.50 & 50 & 75 & 60 & 0 & 50 \\
\hline \hline Bone era/scal & 25.00 & 0 & 50 & 40 & 0 & 0 \\
\hline
\end{tabular}

Secondary effects like perilesional edema and mass effect were commonly seen in all high grade astrocytomas and larger lesions like DIG, PNET and ependymomas.

Oligodendroglioma was characteristically devoid of any secondary effects. Hydrocephalus was seen in $50 \%$ of high grade astrocytomas and ependymomas. Perilesional edema and mass effect were less commonly seen in low grade astrocytomas (37.5\% cases). Bone scalloping was seen in both cases of DIG.

Table 5.10- Post contrast features of intraaxial tumors (in \%)

\begin{tabular}{|c|c|c|c|c|c|c|c|}
\hline \multicolumn{2}{|c|}{ Postcontrast features } & LGA & HGA & NMNG & PNET & OLIGO & EPEND \\
\hline \multirow{3}{*}{ Enhancement } & Mild & 62.5 & 25 & 25 & 0 & 100 & 0 \\
\hline & Mod & 37.5 & 50 & 25 & 40 & 0 & 50 \\
\hline & intense & 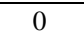 & 25 & 50 & 60 & 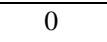 & 50 \\
\hline \multirow[t]{2}{*}{ Pattern } & Hom & 87.5 & 0 & 25 & 0 & 50 & 0 \\
\hline & heter & 12.50 & 100 & 75 & 100 & 50 & 100 \\
\hline \multicolumn{2}{|c|}{ Necrosis/cyst } & 50 & 100 & 100 & 100 & 100 & 50 \\
\hline \multirow[t]{2}{*}{ Margin } & sharp & 75 & 0 & 100 & 100 & 100 & 100 \\
\hline & Ill def & 25 & 100 & 0 & 0 & 0 & 0 \\
\hline
\end{tabular}

Low grade astrocytomas predominantly showed homogenous post contrast enhancement in all but 1 case and the intensity was mild (62.5\%) to moderate (37.5\%), whereas high grade astrocytomas showed heterogenous enhancement with necrotic areas in $100 \%$ of cases and the amount of enhancement was variable.

PNETs showed heterogenous post contrast enhancement in $100 \%$ and NMNGs in $75 \%$ of cases. In our study of 2 cases of oligodendrogliomas, heterogenous enhancement was seen in 50\% and the enhancement was mild in both the cases. Both the cases of ependymoma showed heterogenous enhancement and the enhancement was moderate to intense.

\section{Extraaxial tumors- 11 cases.}

Table - 5.11.Distribution of extraaxial tumors.

\begin{tabular}{|l||l||c||c||c||}
\hline \hline \multirow{3}{*}{ Sellar } & TUMOR & $\begin{array}{c}\text { NUMBER OF } \\
\text { CASES }\end{array}$ & $\begin{array}{c}\text { \% OUT OF } \\
\text { EXTRA AXIAL }\end{array}$ & $\begin{array}{c}\text { \% OUT OF } \\
\text { SUPRATENTORIAL }\end{array}$ \\
\hline \hline \multirow{3}{*}{ Pineal } & Craniopharyngioma & 5 & 45.45 & 13.88 \\
\cline { 2 - 5 } & Germinoma & 1 & 9.10 & 2.77 \\
\cline { 2 - 5 } & Pitutary adenoma & 1 & 9.10 & 2.77 \\
\cline { 2 - 5 } & Germinoma & 1 & 9.10 & 2.77 \\
\cline { 2 - 5 } & Pineoblastoma & 1 & 9.10 & 2.77 \\
\hline \hline \multirow{3}{*}{ Other } & CPP & 1 & 9.10 & 2.77 \\
\cline { 2 - 5 } & Meningioma & 1 & 9.10 & 2.77 \\
\hline
\end{tabular}

Among Supratentorial extraaxial tumors, craniopharyngioma is the commonest accounting for $46 \%$ of extra axial and $13.8 \%$ of all Supratentorial tumors. Overall sellar and suprasellar area is the commonest of extraaxial location ( 7 cases) followed by pineal region in our study ( 2 cases).

Table-5.12. Sex distribution of Extraaxial lesions.

\begin{tabular}{|l||r|r||}
\hline \multicolumn{1}{|c|}{ Tumors } & \multicolumn{2}{c|}{ Sex } \\
\cline { 2 - 3 } & $\mathrm{M}$ & $\mathrm{F}$ \\
\hline \hline Sellar lesions & 5 & 2 \\
\hline \hline Pineal gland lesions & 2 & 0 \\
\hline \hline CPP & 1 & 0 \\
\hline \hline Meningioma & 0 & 1 \\
\hline
\end{tabular}


M: F ratio of overall extraaxial lesions is $2.67: 1$ and male predominance was noted in craniopharyngiomas and germinomas. We got a single case of meningioma in a female.

Table 5.13- Age distribution of extraaxial lesions

\begin{tabular}{|l||c||c||c||c||}
\hline \hline Age $(\mathrm{yrs})$ & Sellar & Pineal & CPP & Meningioma \\
\hline \hline$<1$ & 0 & 0 & 0 & 0 \\
\hline \hline $1-5$ & 0 & 0 & 1 & 0 \\
\hline \hline $6-10$ & 2 & 0 & 0 & 0 \\
\hline \hline $11-15$ & 2 & 0 & 0 & 0 \\
\hline \hline $16-18$ & 3 & 2 & 0 & 1 \\
\hline
\end{tabular}

Table- 5.14. Pre-contrast features of Sellar lesions.

\begin{tabular}{||l||c||c||c||}
\hline \multicolumn{1}{|c|}{ Features } & Cranio (\%) & S. germinoma (\%) & Pit. Adenoma (\%) \\
\hline \hline Hyperdense & 60 & 100 & 100 \\
\hline \hline Isodense & 20 & 0 & 0 \\
\hline \hline Hypodense & 20 & 0 & 0 \\
\hline \hline Calcifications & 80 & 100 & 100 \\
\hline \hline Multiplicity & 0 & 0 & 0 \\
\hline
\end{tabular}

Craniopharyngioma was hyperdense in $60 \%$ cases, isodense in $20 \%$ and hypodense in $20 \%$. Calcification was noted in 4 cases $(80 \%)$. Both pituitary adenoma and sellar germinoma were hyperdense on NECT and showed evidence of intracranial calcifications.

Table- 5.15. Secondary effects by sellar lesions

\begin{tabular}{|c|c|c|c|}
\hline Features & Cranio(\%) & S. germinoma $(\%)$ & Pit adenoma $(\%)$ \\
\hline PLE & 20 & 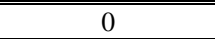 & 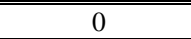 \\
\hline Mass effect & 100 & 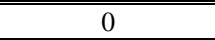 & 100 \\
\hline Hydrocephalus & 60 & 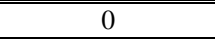 & 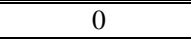 \\
\hline Bone ero/scal & 100 & 100 & 100 \\
\hline
\end{tabular}

Bone erosion/ scalloping was the commonest secondary effect by the extraaxial lesions noted in all the sellar lesions in our study, followed by mass effect and hydrocephalus.

Table 5.16- Post contrast features of Sellar lesions

\begin{tabular}{|c|c|c|c|c|}
\hline \multicolumn{2}{|c|}{$\begin{array}{c}\text { Features } \\
\text { (post-contrast) }\end{array}$} & \multirow{2}{*}{$\begin{array}{c}\text { Cranio } \\
20\end{array}$} & \multirow{2}{*}{$\begin{array}{c}\text { Pit adenoma } \\
0\end{array}$} & \multirow{2}{*}{$\begin{array}{c}\text { S.Germinoma } \\
\\
0 \\
\end{array}$} \\
\hline \multirow{3}{*}{ Enhancement } & mild & & & \\
\hline & mod & 60 & 100 & 0 \\
\hline & intense & 20 & 0 & 100 \\
\hline \multirow[t]{2}{*}{ Pattern } & Hom & 20 & 0 & 100 \\
\hline & " Heter & 80 & 100 & 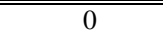 \\
\hline \multicolumn{2}{|l|}{ Necrosis/cyst } & 80 & 100 & 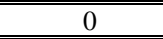 \\
\hline \multirow[t]{2}{*}{ Margin } & sharp & 100 & 100 & 100 \\
\hline & Ill def & 0 & 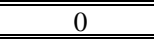 & 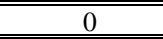 \\
\hline
\end{tabular}

Moderate post contrast enhancement was the commonest pattern of enhancement seen amongst sellar lesions, except in suprasellar germinoma which showed intense homogenous post contrast enhancement. Necrosis /cyst formation was noted in 5 cases (71.4\%). Margins were sharp and well defined in all 7 sellar lesions in our study. 
Table- 5.17-Precontrast features of other extraxial lesions

\begin{tabular}{|c|c|c|c|}
\hline $\begin{array}{c}\text { Features } \\
\text { (pre-contrast) }\end{array}$ & Pineal lesions & $\mathrm{CPP}$ & Meningioma \\
\hline Hyperdense & 2 & 1 & 0 \\
\hline Isodense & 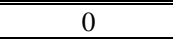 & 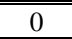 & 1 \\
\hline Hypodense & 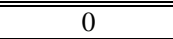 & 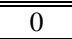 & 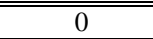 \\
\hline "Calcifications & 2 & 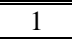 & 1 \\
\hline Multiplicity & 0 & 0 & 0 \\
\hline
\end{tabular}

Both pineal lesions, germinoma and pineoblastoma were hyperdense on NECT and showed calcifications. In the patient of pineal germinoma we found a synchronous suprasellar lesion. We studied a single case of meningioma which was hypodense on NECT and contained calcifications.

Table -5.18 . Secondary effects by other extraaxial lesions.

\begin{tabular}{||l||c||c||c||}
\hline \multicolumn{1}{|c|}{ Secondary effects } & Pineal lesions & CPP & Meningioma \\
\hline \hline PLE & 0 & 1 & 1 \\
\hline \hline Bone ero/scal & 0 & 0 & 0 \\
\hline \hline Mass effect & 1 & 0 & 0 \\
\hline \hline Hydrocephalus & 2 & 1 & 0 \\
\hline
\end{tabular}

Hydrocephalus was the commonest secondary effect seen in pineal lesions and choroid plexus papilloma. Mild perilesional edema was seen in the solitary case of meningioma.

Table- 5.19. Post-contrast features of other extra-axial lesions.

\begin{tabular}{|c|c|c|c|c|}
\hline \multicolumn{2}{|c|}{$\begin{array}{c}\text { Features } \\
\text { (post-contrast) }\end{array}$} & \multirow{2}{*}{$\begin{array}{c}\begin{array}{c}\text { Pineal } \\
\text { Lesions }\end{array} \\
0 \\
\end{array}$} & \multirow{2}{*}{$\begin{array}{c}\text { CPP } \\
0 \\
\end{array}$} & \multirow{2}{*}{$\begin{array}{c}\text { Meningioma } \\
\\
0 \\
\end{array}$} \\
\hline \multirow{3}{*}{ Enhancement } & mild & & & \\
\hline & $\bmod$ & 1 & 0 & 1 \\
\hline & intense & 1 & 1 & 0 \\
\hline \multirow[t]{2}{*}{ Pattern } & Hom & 1 & 0 & 1 \\
\hline & heter & 1 & 1 & 0 \\
\hline \multicolumn{2}{|l|}{ Necrosis/cyst } & 1 & 1 & 1 \\
\hline \multirow[t]{2}{*}{ Margin } & sharp & 2 & 1 & 1 \\
\hline & Ill def & 0 & 0 & 0 \\
\hline
\end{tabular}

Pineal germinoma showed intense uniform post contrast enhancement whereas, pineoblastoma showed moderate heterogenous enhancement.

TABLE-5.20

CT ACCURACY

\begin{tabular}{|c|c|c|}
\hline CT DIAGNOSIS & $\underset{(\mathrm{n})}{\text { NUMBER }}$ & PERCENTAGE (\%) \\
\hline Correct & 33 & 91.66 \\
\hline Wrong & 3 & 8.33 \\
\hline TOTAL & 36 & 100.00 \\
\hline
\end{tabular}




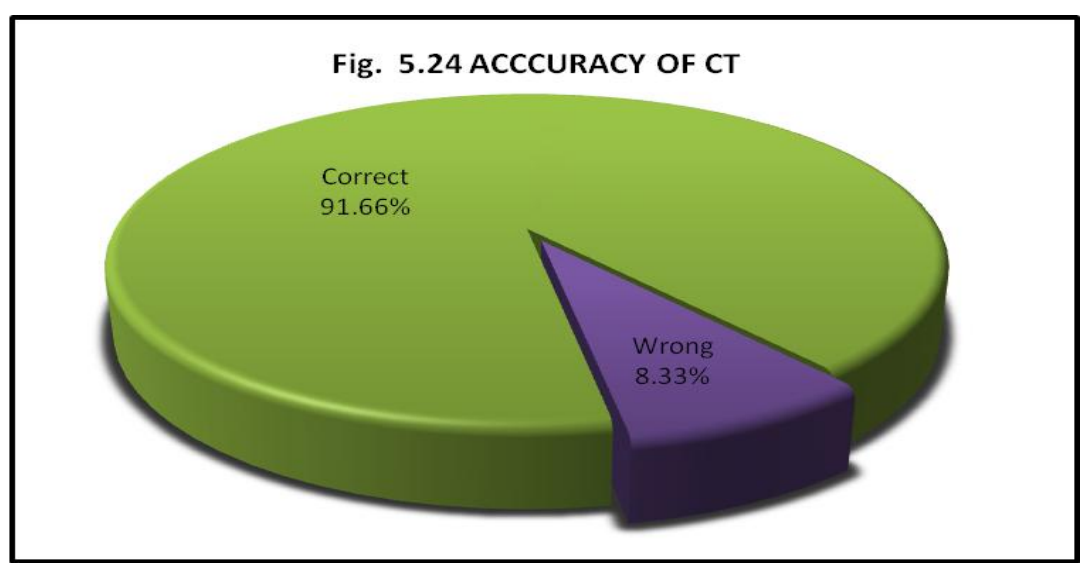

In the present study, CT was found to be accurate in $91.66 \%$ of cases. One case of CT diagnosis of diffuse low grade astrocytoma came out to be high grade on HPE. In a case of pineal germinoma CT had failed to diagnose a synchronous sellar germinoma which was detected on subsequent MRI. A case of ependymoma was misdiagnosed as supratentorial PNET.

Table-5. 21 Various Supratentorial tumors in our study.

\begin{tabular}{|c|c|c|}
\hline TUMORS & $\underset{(\mathrm{n})}{\mathrm{NUMBER}}$ & PERCENTAGE (\%) \\
\hline Pilocytic astrocytomas & 3 & 8.33 \\
\hline Diffuse infiltrating LGA & 2 & 5.50 \\
\hline Optic pathway glioma & 2 & 5.50 \\
\hline SEGCA & 1 & 2.77 \\
\hline Anaplastic astrocytoma & 2 & 5.50 \\
\hline GBM & 2 & 5.50 \\
\hline DIG & 2 & 5.50 \\
\hline Central neurocytoma & 1 & 5.00 \\
\hline Ganglioglioma & 1 & 2.77 \\
\hline Supratentorial PNET & 5 & 13.88 \\
\hline Oligodendroglioma & 2 & 5.50 \\
\hline Ependymoma & 2 & 5.50 \\
\hline Craniopharyngioma & 5 & 13.88 \\
\hline Pitutary adenoma & 1 & 2.77 \\
\hline Sellar germinoma & 1 & 2.77 \\
\hline Pineal germinoma & 1 & 2.77 \\
\hline Pineoblastoma & 1 & 2.77 \\
\hline Choroid plexus papilloma & 1 & 2.77 \\
\hline Meningioma & 1 & 2.77 \\
\hline TOTAL & 36 & 100.00 \\
\hline
\end{tabular}

\section{Discussion}

Many comprehensive studies have studied pediatric brain tumors. The conclusion reached by any supratentorial pediatric brain tumor survey vary according to the source of material and the age group studied, the percentage of biopsy proven entities, the geographic areas encompassed, the type of researchers and the scope of diagnostic modalities used to evaluate the patients enrolled in series. 


\section{Epidemiology}

In our study of 36 supratentorial tumors, we found 25 intraaxial lesions and 11 extraaxial lesions. Overall the commonest tumor group was astrocytomas accounting for $33.3 \%$ ( 12 cases), followed by craniopharyngiomas (5 cases) and PNET (5 cases) each accounting for $13.8 \%$.

Our study showed close correlation with Rosemberg et $a l^{28}$ (2005) who concluded that in the cerebral compartment, pilocytic astrocytomas were the single most frequent tumors (18\%), followed by diffuse astrocytomas (14\%), medulloblastomas/PNET (11\%), and craniopharyngiomas (11\%).

Our study also correlated well with studies of Haque et $a l^{3}$ (2010) who in their study concluded that in the supratentorial region the common tumors are astrocytoma (25\%), craniopharygioma (14\%), suprasellar germinoma, and PNET (7\%).

\section{Intraaxial tumors. Astrocytomas.}

Astrocytomas are the most common primary pediatric brain tumors. In our study low grade astrocytomas accounted for $22.20 \%$ whereas high grade gliomas accounted for $11.10 \%$ of all pediatric supratentorial tumors and pilocytic astroytoma was the commonest astrocytoma. The ratio of low grade to high grade tumors was 2:1. This correlated with studies of Higano et al ${ }^{4}(1997)$ where out of 17 astrocytomas, 10 cases were low grade and remaining 7 were high grade and Naseem Ahmed ${ }^{29}$ et al (2007), where they found pilocytic astrocytoma as the commonest, with 11 low grade and 6 high grade tumors among 17 astrocytomas giving a ratio of $1.8: 1$.

\section{Low grade astrocytomas}

Low grade astrocytomas accounting for $22.2 \%$ of all pediatric Supratentorial tumors and $32 \%$ of intraaxial tumors were the single largest group in our study. The male: female ratio was 1.6:1. Most of the tumors were found in the age group of 6-10 years ( 4 cases).

Our study included 3 pilocytic astrocytomas, 2 diffuse infiltrating low grade astrocytomas, 2 optic pathway gliomas, and 1 SEGCA.

On plain CT $62.5 \%$ lesions were hypodense (5 out of 8 cases) and calcification was noted in $37.5 \%$. Perilesional edema was seen in $37.5 \%$ ( 3 cases)

Mild homogenous post contrast enhancement was the commonest pattern of enhancement noted in $62.5 \%$ cases with cystic changes noted in $50 \%$ of cases.

Tumor margins were blurred in 2 of the cases located in the frontal lobe indicating diffuse infiltrating nature of neoplasm.

\section{Pilocytic astrocytoma.}

Epidemiology-

Amongst low grade astrocytomas, pilocytic astrocytoma was the commonest accounting for $25 \%$ of all the astrocytomas in our study which was in accordance with Rosemberg et al ${ }^{28}(2006)$ and Harmouch et al ${ }^{32}$ (2012) who found pilocytic astrocytomas as the commonest tumors in their study.

All 3 tumors in our study was found in age group of 6-10 years which correlated with study of Dolecek et al ${ }^{1}$ (2012) who found predominance of pilocytic astrocytomas in age group of 5-9 years.

CT features-

All 3 cases of Pilocytic astrocytomas assumed a common appearance of cystic lesion with a mural nodule or peripheral enhancing solid components in our study. The solid component of the lesion was hypodense in all 3 cases and showed moderate post contrast enhancement in $2(66.6 \%)$ cases. These features correlated with study by Lee et $a l^{37}(1989)$ who stated the tumor matrix was most often hypo or isodense with marked enhancement of mural nodule.

Mild perifocal edema was seen in 1 case whereas no edema was seen in other 2 cases. This correlated with Lee et $^{3 l^{37}}$ (1989) who stated edema is rarely associated with pilocytic astrocytomas.

Cysts of varying sizes were seen in all three cases which was in accordance with studies by D Afra et al ${ }^{36}(1986)$ and Lee et $a l^{37}(1989)$.

HPE confirmation was obtained in one case of pilocytic astrocytoma.

\section{Optic pathway glioma}

Of the 2 cases of optic pathway glioma, one was a well defined fusiform enlargement of optic nerve with extension to optic chiasm, whereas the second lesion was ill defined.On CT they appeared as hypodense $(50 \%)$ to isodense $(50 \%)$ lesions which showed mild homogenous post contrast enhancement. These findings correlated with Osborn $^{62}$ (2013) who stated that astrocytomas of optic pathway show variable enhancement. 


\section{Diffuse infiltrating low grade astrocytoma.}

In our study we found 2 cases of diffuse low grade astrocytomas. Both the lesions were found in frontal lobe and in the age group of 16-18 years.

On plain scan the lesions appeared hypodense in 1 case $(50 \%)$ and isodense in other case $(50 \%)$. Calcification was seen in 1 case. Both the cases showed faint contrast enhancement. Margins were ill defined in both the cases.This was in correlation with Feng et al ${ }^{89}(2012)$ who concluded that diffuse low grade astrocytomas demonstrated abnormal density with obscure margin, mild peritumoral edema and mass effect. Patchy enhancement, nodular enhancement, or irregular ring-like enhancement or no appreciable enhancement was noted on post-contrast MR or CT scans.

\section{Subepndymal giant cell astrocytoma}

In our study we found a single case in a 16 year male patient with tuberous sclerosis. This corresponded with Nabbout et al ${ }^{43}(1999)$ who stated that SEGCAs are present in $5 \%$ to $10 \%$ of the cases of tuberous sclerosis

Patient presented with symptoms of seizures, which is one of the common presenting symptoms in a patient of tuberous sclerosis.

On NECT scans the lesion was noted as a well circumscribed hyperdense lesion in foramen of Monro showing intralesional calcifications, inciting perilesional edema.

On contrast study moderate heterogenous enhancement was noted. Our study correlated with Adriaensen $\mathrm{et}^{\mathrm{at}} \mathrm{l}^{45}$ (2009) who used the definition of a partially calcified lesion showing marked enhancement located near the foramen of Monro, measuring at least $1 \mathrm{~cm}$ in maximum axial diameter as the CT criterion similar to that concluded by Nabbout et al ${ }^{43}(1999)$.

\section{High grade astrocytomas.}

Epidemiology-

In our study, high grade tumors were $33.3 \%$ of astrocytomas and accounted for $11.1 \%$ of all Supratentorial tumors. Out of 4, 2 were anaplastic type and 2 of GBM type. Study by Fangusaro et $a l^{46}(2012)$ concluded that the most common histologies amongst high grade gliomas as anaplastic astrocytoma (WHO Grade III) and GBM (WHO grade IV).

Out of 4 cases M: F ratio was 1:1, which correlated with conclusions of Fangusaro et al ${ }^{46}(2012)$ who found in most series that distribution between males and females is equal.

$50 \%$ of the tumors were hemispheric in location followed by basal ganglia $(25 \%)$ and periventricular locations (25\%). 50\% of the cases are seen in the age group of 16-18 years without any sex predilection. Our study correlated well with Fangusaro et al ${ }^{46}(2012)$ who stated $33 \%$ of $35-50 \%$ are located within the cerebral hemispheres and found the highest incidence of supratentorial HGG among children is in patients 15-19 years . Broniscer and Gajjar et $\mathrm{l}^{47}$ (2004), also found a higher incidence of high grade astrocytomas in 15-19 year age group.

Raised ICT was the commonest presenting features which was seen in 75\% patients which correlated with study of Fangusaro et $a l^{46}(2012)$ who found that presenting signs in high grade tumors are often due to increased intracranial pressure.

\section{CT features}

On NECT $25 \%$ of the cases showed calcification. All 4 cases showed perilesional edema and mass effect. 50\% cases were isodense, 25\% hypodense and 25\% hyperdense on NECT but all the tumors showed heterogenous pattern of enhancement with non-enhancing areas within suggestive of necrosis. Tumor margins were ill defined in all the cases suggesting infiltrative pattern of growth. These features correlated with studies by Leeds et al ${ }^{90}(1984)$ and Ahmed Massaryk et $a l^{91}$ (2007) who stated that these tumors typically appear on noncontrast CT as heterogeneous masses with irregular borders of normal or slightly increased density with central cavitation of diminished attenuation. The irregular hyperdense borders demonstrate avid contrast enhancement.

Cage $e t a l^{50}(2012)$ stated that on (CT) scans high grade tumors are seen as an irregular isodense or hypodense lesion which show heterogeneous post contrast enhancement corresponded to our study .

\section{Neuronal and mixed neuronal glial tumors}

In our study we found 4 cases of NMNGs which included 2 DIG, 1 ganglioglioma and a case of central neurocytoma. As a group they accounted for $11.1 \%$ of all supratentorial tumors. A study by Rosemberg et al ${ }^{28}(2005)$ found that the frequency of neuronal and mixed neuronal glial tumors is increasing $(8 \%)$. 
DIG

We found 2 cases of DIG in our study, both in males in the age group $<1$ year which correlated with Ganesan et $a l^{92}$ (2006) who observed that DIG is common in male children and these tumors are generally observed in the first 18 months of life, especially in the first 4 months.

Both patients presented with clinical signs of raised ICT which correlated with study by Shin et al ${ }^{65}$ (2002).

They were seen as large hemispheric tumors occupying more than one lobe with both solid and cystic components. The solid component was plaque or nodular with hyperdense attenuation on NECT and showed intense heterogenous post contrast enhancement in both cases. These findings were similar in a case report by Avci E et al ${ }^{93}$ (2008) and M Gonzalez et al ${ }^{68}$ (2011)who found that more than one lobe is affected in over $60 \%$ of cases and found DIG as a giant mass with an aggressive radiological appearance and a cystic component that exhibited marked contrast uptake.

\section{Ganglioglioma}

We studied a single case of Ganglioglioma in a boy aged 13 years, who presented with seizures.

On NECT we found a hypodense predominantly cystic mass lesion in temporal lobe with peripheral calcification. Mild enhancement noted in the peripheral aspect of the lesion.

Our study correlated with Castillo et al ${ }^{67}(1990)$ who described Ganglioglioma as a cystic lesion with mural nodule seen in $40 \%$ of cases.

Study by Shin $e a^{65}$ (2002) stated that calcification is seen in about $40 \%$ of gangliogliomas.

Im S H et al ${ }^{94}(2002)$ stated that seizure was the most common presenting symptom (85\%) and found tumor calcification in $54.5 \%$ cases, cystic components in $50 \%$ and tumor enhancement in 53\%. Our findings correlated with these studies.

\section{Central neurocytoma}

We studied a case of central neurocytoma in a female adolescent aged 17 years. On plain CT it appeared as a heterogenously isodense lesion in the lateral ventricle near foramen of Monro. On post contrast study the lesion was noted showing moderate heterogenous enhancement.

The findings in our study corresponded to the studies by Goergen et $\mathrm{l}^{70}(1992)$ and Shin et al ${ }^{65}(2002)$ who had concluded in their studies that central neurocytoma is typically a lateral ventricular mass attached to septum pellucidum, which is iso to slightly hyperdense on NECT and shows heterogenous enhancement .

\section{Supratentorial PNET.}

PNETs were found to be the second most common intraaxial tumors accounting for $20 \%$ intraaxial tumors and $13.8 \%$ of all supratentorial tumors. $40 \%$ of the tumors were found in 2-5 year age group and another $60 \%$ between 5-10 yr age group. This correlated with studies of Haque et al ${ }^{3}(2010)$, where PNETs constituted $7 \%$ of all Supratentorial tumors.

The most common clinical presentation was raised ICT seen in $60 \%$ (3 cases) of patients. All the tumors were hemispheric in location with $60 \%$ of them involving more than one lobe. Dai et al ${ }^{72}$ (2003) found hemispheric location in 8 out of 13 patients in their study and M.Z. Boudawara et al ${ }^{95}$ (2001) found that clinical presentation in PNETs was dominated by a syndrome of intracranial hypertension.

All 5 lesions were hyperdense on NECT and showed intralesional calcification. Mass effect was a common feature seen in $80 \%$ cases. Scalloping of adjacent calvaria is noted in $40 \%$ of cases. These findings correlated with Dai et $a l^{72}(2003)$ who in their study found that all cases were hyperdense on NECT with a significant midline shift observed on all scans. M.Z. Boudawara et al ${ }^{95}(2001)$ in their study stated that PNET in all cases, were large and presented triple component: solid, cystic and calcified parts.

$80 \%$ cases showed intense heterogenous post contrast enhancement with ill defined margins in $20 \%$ of cases. Cysts were evident in $66 \%$ of the cases and heterogeneous enhancement was noted in all cases in the study by Dai et $_{\text {al }}{ }^{72}(2003)$.

\section{Oligodendroglioma.}

In our study we found two cases of oligodendroglioma, both presenting with complaints of seizures with a mean age of 16 years. Both the tumors were noted in frontal lobe. This finding correlated with Lee et al ${ }^{52}(1989)$ who stated oligodendrogliomas most often present as supratentorial frontal tumors.

On NECT, 1 case (50\%) was hypodense and another (50\%) was isodense with calcification seen in both the cases. Perilesional edema and mass effect were noticeably absent in both the cases. On contrast examination, mild enhancement was noted in both the cases but the pattern was homogenous in one of the cases, while heterogeneous in the other. These findings correlated with Lee et al ${ }^{22}$ (1989) who described oligodendroglial tumors as large, calcified, and poorly to non-enhancing peripheral tumors with calcification in 
$60 \%$ cases. Oligodendrogliomas were hypodense in $60 \%$ cases. Reiche $e t$ al ${ }^{97}$ ( 2002) in their study of 12 low grade oligodendrogliomas, found contrast enhancement in 3 cases, no enhancement in 6 and post contrast scans were not available in other 3.

One of the cases showed ependymal spread to $4^{\text {th }}$ ventricle. Wai hoe et $a l{ }^{96} 2006$ ) reported a case of oligodendroglioma (grade II) with ventricular dissemination.

\section{Ependymal tumors.}

In our study we found 2 cases of ependymal tumors and both were found in 16-18 year age group. Both the patients presented with features of raised ICT and on CT examination were found to be periventricular in location. This correlated with Mermuys et al ${ }^{56}(2005)$ who stated that within the pediatric population, Supratentorial ependymomas are often seen in older childhood.

On NECT both the lesions were large and heterogeneous in appearance. Both the lesions showed calcification, perilesional edema and mass effect whereas hydrocephalus was seen in 1 case. Koeller et al ${ }^{59}(2002)$ stated calcification is a common feature seen $40-80 \%$ cases.

On contrast study both lesions showed moderate to intense heterogenous enhancement. This feature correlated with Yuh et $a l^{60}(2009)$ who stated that ependymomas generally show heterogenous enhancement.

\section{Extraaxial tumors \\ Epidemiology}

In our study extraaxial tumors accounted for 30.5\% (11 cases) of supratentorial tumors and sellar region was the commonest location (7 cases). Craniopharyngioma was the commonest diagnosis accounting for $13.8 \%$ of Supratentorial and $45.45 \%$ of extraaxial tumors.

Male predominance was found in craniopharyngiomas and germinomas in our study.

$54.54 \%$ ( 6 cases) of all extraaxial tumors were found in age group of 16-18 years. Headache (36.36\%) and raised ICT $(27.27 \%)$ were the commonest symptoms in our study.

\section{Craniopharyngiomas}

We studied 5 cases of craniopharyngioma. In 2 cases we got histological confirmation that they belonged to adamantinomatous variety on post operative HPE analysis.

Accounting for $13.8 \%$ of all supratentorial tumors, it was the commonest extraaxial tumor. Haghighatkhah et al ${ }^{98}(2010)$ stated that craniopharyngiomas are the most common non-glial pediatric brain tumor.Haque et $\mathrm{al}^{3}(2010)$ found craniopharyngiomas as the second most common (14\%) tumor in their study of pediatric brain tumors which is similar to our study.

3 cases $(60 \%)$ were found in the age group of $16-18$ years and 2 cases $(40 \%)$ in the age group of 11 15years. Male: female ratio was 3:2.

On NECT they were predominantly hyperdense $(60 \%)$ and both peripheral as well as coarse intralesional calcification was noted in $80 \%$. Cystic changes of varying sizes were noted in 4 cases. Post contrast study revealed moderate to intense heterogenous post contrast enhancement. Sellar erosion was seen in $60 \%$ of cases and perilesional edema in $20 \%$ of cases. Our study correlated with study by Haque et al $l^{3}$ (2010) where calcification was present in $87.5 \%$ cases and contrast enhancement in $100 \%$ cases.

Haghighatkhah et al ${ }^{98}(2010)$ stated in their study that on CT scan, the pediatric type is predominantly suprasellar and calcified cystic mass with solid components in $90 \%$ of cases.

\section{Pituitary adenoma} acromegaly.

We studied a single case of pituitary adenoma in a 18 year old male patient with clinical diagnosis of

Keil et al ${ }^{99}(2008)$ stated the frequency of pituitary adenomas increases during adolescence but they remain relatively rare tumors which correlated with our study.

Webb and Prayson et al ${ }^{100}(2008)$ studied 20 tumors. Of these 9 adenomas stained solely for prolactin, 5 for adrenocorticotropic hormone, and 3 for growth hormone.[96] Chaudhary and Bano et al ${ }^{101}$ (2012)stated Somatotropinomas or growth hormone producing adenomas compromise approximately $5-15 \%$ of pituitary tumors in children and adolescents.

On plain CT it was a heterogenous predominantly hyperdense lesion with intralesional calcification. On post contrast study the lesion showed intense enhancement of the solid component with central non enhancing areas. These findings correlated with Osborn et al $^{62}(2013)$ who has stated that cystic changes is common (in 15$20 \%$ cases) and moderate but heterogeneous enhancement is common on CECT . This case was followed up with MR scanning which confirmed the diagnosis by its characteristic location and imaging findings. 


\section{Germinomas .}

In our study we found 2 cases of germinomas, one in suprasellar and another case where there were synchronous pineal and suprasellar germinomas.

\section{Suprasellar germinoma}

We studied a single case of suprasellar germinoma which presented in a 10 year old male with headache. On NECT it was seen as a homogenously hyperdense mass lesion containing fine calcific densities within .On post contrast study the lesion shows intense enhancement.

\section{Pineal germinoma}

This case was seen in a male patient aged 18 years who presented with symptoms of headache. Plan CT scans showed a homogenously hyperdense mass lesion engulfing normal pineal calcification which showed homogenous post contrast enhancement. CT had missed a synchronous suprasellar lesion which was detected on follow up MR scans.

Our findings in germinomas correlated with Kaprelyan $\mathrm{et}^{\mathrm{al}}{ }^{76}(2006)$, who found a 5-10\% incidence of synchronous sellar and pineal tumors and stated that CT scans demonstrated well circumscribed tumor lesions with a homogeneous contrast enhancement in the suprasellar and pineal germinomas.

\section{Pineoblastoma}

A 13 year male patient presented with clinical signs of lateral gaze palsy. Plain CT revealed a large hyperdense lesion with peripheral calcifications showing moderate heterogeneous post contrast enhancement .Hydrocephalus was noted in our case.

Ganti et al ${ }^{102}$ (1986) reported moderate enhancement with a small central lucency in $80 \%$ cases of pineoblastoma in their study which correlated with our findings.

Smith et al ${ }^{87}(2010)$ stated that CT reveals a large, lobulated, typically hyperattenuating mass. The pineal calcifications, if seen, may appear exploded at the periphery of the lesion which correlates with our study.

\section{Choroid plexus papilloma}

We studied a single case of papilloma in a 2 year old male patient with features of raised ICT. This was in accordance with Naeini et $a l^{61}(2009)$ who stated that most common trigonal masses in young children $(<5$ years) and have a marked predominance in boys.

On plain CT, it was seen as a lobulated hyperdense mass lesion in lateral ventricle with intralesional calcifications. All the ventricles were grossly dilated suggestive of communicating hydrocephalus. On post contrast study the lesion shows moderate heterogenous post contrast enhancement. These findngs were similar to Naeini et $a l^{61}$ (2009) who stated that CPPs typically appear as lobulated, intraventricular masses that are isoor mildly hyperdense on unenhanced $\mathrm{CT}$ and homogeneously enhancing after the injection of contrast material with calcifications in about $25 \%$ of cases. They have also found that aggressive papillomas may incite perifocal edema suggesting growth into adjacent white matter in our case.

\section{Meningioma.}

In our study we found a case of meningioma in a 17 year old female who presented with symptoms of headache. On examination it was noted as an extraaxial isodense parasagittal mass lesion was noted on NECT with a trapped arachnoid cyst which was an atypical feature. On post contrast study, the lesion showed moderate homogenous post contrast enhancement. Intralesional calcific densities were noted .This correlated with Tufan $\mathrm{K}$ et $a l^{81}(2005)$ who stated that atypical meningiomas are more common in childhood and adolescence on comparison with adults.

\section{CT accuracy:}

Computed Tomography was accurate in delineation of the nature of lesion and extension in most of the cases. In the present study, CT was positive in $91.66 \%$ of pediatric supratentorial tumors.

One case of CT diagnosis of diffuse low grade astrocytoma came out to be of high grade on HPE. In a case of pineal germinoma CT had failed to diagnose a synchronous sellar germinoma which was detected on subsequent MRI. A case of ependymoma was misdiagnosed as supratentorial PNET.

The present study correlated well with the study of Khalid et $a l^{6}$ (2009), who reported an accuracy of $86.67 \%$ for CT on comparison with histopathology.

Haque $\mathrm{et} \mathrm{al}^{3}$ (2010) reported an overall accuracy of $95 \%$ to $97 \%$ with CT as a diagnostic modality in preoperative diagnosis of brain tumors in their study. For astrocytomas and craniopharyngiomas the diagnostic accuracy with CT was $95.2 \%$ and $97.7 \%$ respectively. They concluded that CT is an invaluable imaging modality in preoperative diagnosis of pediatric brain tumor due to its excellent characterization of tumors. 


\section{Summary}

Thirty six (36) cases of supratentorial tumors were evaluated by computed tomography in the Department of Radiodiagnosis, Assam Medical college \& Hospital, Dibrugarh to study their distribution, pre and post contrast features and to localize and assess the extent of tumors.

$\square \quad$ Out of the 36 cases, 25 lesions were intraaxial and 11 were extraaxial in distribution. The commonest tumors in our study were low grade astrocytomas (22.22\%), followed by Supratentorial PNETs $(13.8 \%)$ and craniopharyngimas $(13.8 \%)$

$\square \quad$ Male: Female ratio in our studies was 1.27:1 for intraaxial lesions, 2.67:1 for extraaxial lesions and 1.57:1 for overall tumors. Male predominance was seen in DIG and germinomas.

$\square \quad$ Low grade astrocytomas and PNET were predominantly seen in the age group of 6-10 years, whereas high grade astrocytomas, oligodendrogliomas and sellar lesions predominated in adolescent age group (16-18 years).

$\square \quad$ Raised ICT and headache were the common clinical features with which patients presented in our study.

$\square \quad$ Pilocytic astrocytoma was the commonest of all astrocytomas (25\%). All 3 tumors in our study assumed a common appearance of a cystic lesion with a mural nodule or peripheral enhancing solid component.

$\square \quad$ Amongst high grade astrocytomas, 2 were anaplastic astrocytomas and 2 were GBM. Commonest clinical presentation amongst them were raised ICT. Features that enabled differentiation from low grade tumors were ill defined margins, heterogenous enhancement with large areas of nerosis within.

$\square \quad 2$ cases of DIG were identified typically as large hemispheric masses with both solid and cystic components and presented in age of less than 1 year.

$\square \quad$ A single case of ganglioglioma was seen as cystic lesion in temporal lobe with peripheral calcification, with typical clinical feature of seizures.

$\square \quad$ Supratentorial PNETs were the second most common intraaxial tumors. All the tumors presented in < 10 years with usual CT features of large hemispheric tumors exerting mass effect leading to features of raised ICT.

$\square \quad$ We studied 2 cases of oligodendrogliomas, in which ependymal spread to ventricle was seen in one case.

$\square \quad$ In our study we found 2 cases of ependymal tumors and both were found in 16-18 year age group. Both tumors were periventricular in distribution with internal calcifications.

$\square \quad$ Sellar and suprasellar region is the commonest extraaxial location amongst Supratentorial tumors in which craniopharyngiomas was the commonest.

$\square \quad$ Headache and diminished vision were the common presenting features in craniopharyngomas. Calcfication and cysts of "machine oil" nature were noted in 4 out of 5 cases.

$\square \quad$ A case of pineal germinoma was studied, in which a synchronous sellar lesion was later detected on follow up MRI which was missed on initial CT scans.

$\square \quad$ Pituitary macroadenoma with characteristic CT features was noted in an adolescent male with clinical diagnosis of acromegaly.

$\square \quad$ Choroid plexus papilloma was detected in a 2 year old boy in characteristic location of trigone of ventricle.

$\square \quad$ Atypical meningioma with trapped arachnoid cyst was detected in an adolescent female.

$\square \quad$ Computed tomography permitted accurate localization of Supratentorial tumors in pediatric age group with accurate characterisation in most cases. Calcifications, hyperdense nature of tumors due to cellularity were well appreciated. CT obviated the need for anaesthesia in most cases due to faster acquisition when compared to MRI.
Abbreviations

\begin{tabular}{|c|}
\hline $\begin{array}{l}\text { Astro } \\
\text { CPP } \\
\text { Dim } \\
\text { Ero } \\
\text { Ependym } \\
\text { h/o } \\
\text { Heter } \\
\text { HGA } \\
\text { Hom } \\
\text { Hyper }\end{array}$ \\
\hline
\end{tabular}
Anaplastic
: Astrocytoma
Choroid Plexus papilloma
diminished
erosion
: $\quad$ Ependymoma
History
heterogenous
High grade astrocytoma
Homogenous
Hyperdense 


$\begin{array}{lllll}\square & \text { Hypo } & : & & \text { Hypodense } \\ \square & \text { ICT } & : & & \text { Intracranial tension } \\ \square & \text { Iso } & : & & \text { Isodense } \\ \square & \text { LGA } & : & & \text { Low grade astrocytoma } \\ \square & \text { M:F } & : & & \text { Male:Female } \\ \square & \text { Mod } & : & & \text { Moderate } \\ \square & \text { No/n } & : & \text { Number } \\ \square & \text { Oligo } & : & \text { Oligodendroglioma } \\ \square & \text { N } & : & \text { No } \\ \square & \text { P } & : & \text { Pineal germinoma } \\ \square & \text { PET } & : & & \text { Positron Emission Tomography. } \\ \square & \text { PLE } & : & & \text { Perilesional edema } \\ \square & \text { PNET } & : & & \text { Primitive Neuroectodermal Tumor } \\ \square & \text { S } & : & \text { Suprasellar } \\ \square & \text { SOL } & & : & \text { Space occupying lesion } \\ \square & \text { Scal } & & : & \text { Scalloping } \\ \square & \text { Y } & & : & \text { Yes } \\ \square & \text { Yrs } & : & & \text { Years. }\end{array}$

$\sim$

Masterchart

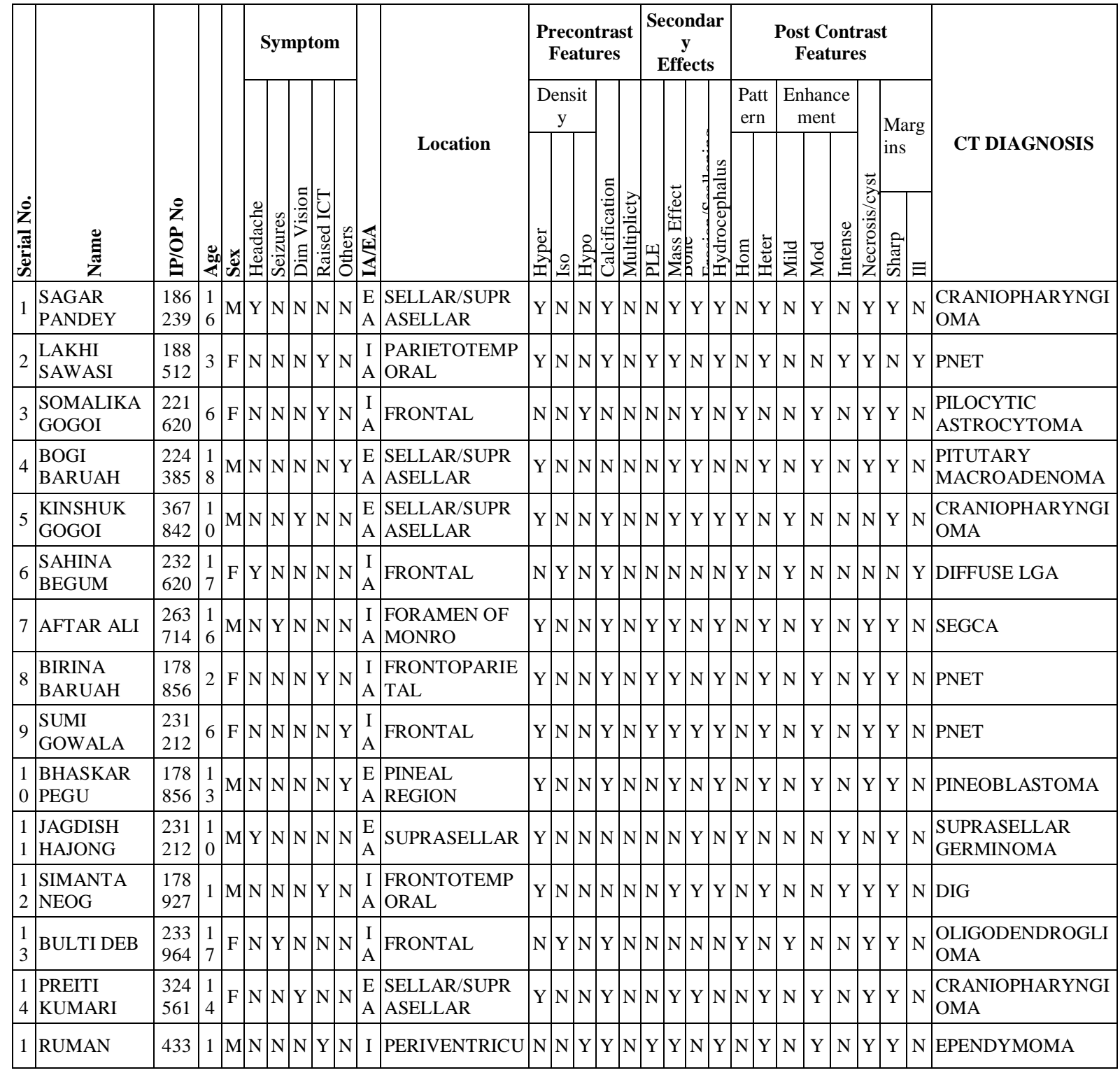




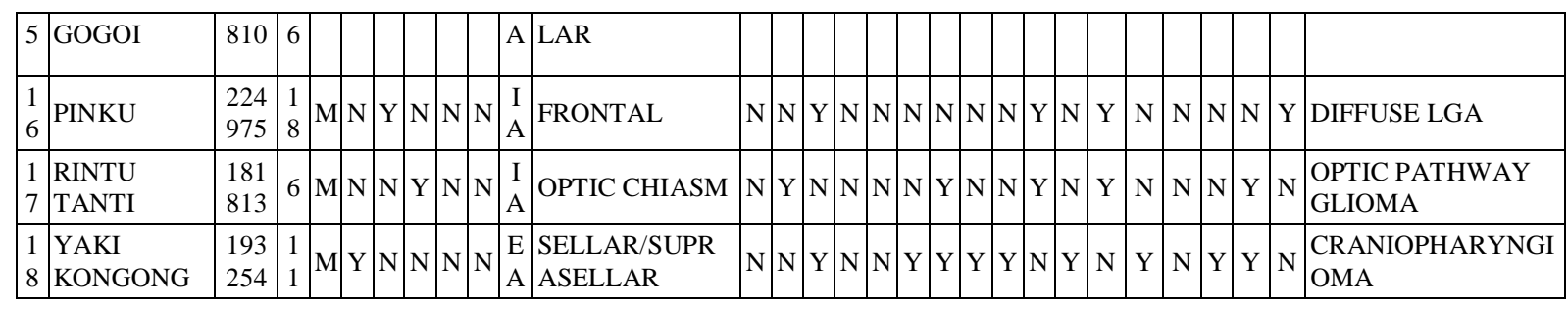

\begin{tabular}{|c|c|c|c|c|c|c|c|c|c|c|c|c|c|c|c|c|c|c|c|c|c|c|c|c|c|c|}
\hline & \multirow[b]{3}{*}{$\underset{\Xi}{\tilde{Z}}$} & \multirow[b]{3}{*}{$\begin{array}{l}\stackrel{0}{z} \\
\text { ô } \\
\hat{=}\end{array}$} & \multirow[b]{3}{*}{ 品 } & \multicolumn{6}{|c|}{ Symptom } & \multirow{3}{*}{ Location } & \multicolumn{4}{|c|}{$\begin{array}{c}\text { Precontrast } \\
\text { Features }\end{array}$} & \multicolumn{4}{|c|}{$\begin{array}{c}\text { Secondar } \\
\mathbf{y} \\
\text { Effects }\end{array}$} & \multicolumn{7}{|c|}{$\begin{array}{l}\text { Post Contrast } \\
\text { Features }\end{array}$} & \multirow{3}{*}{ CT DIAGNOSIS } \\
\hline & & & & & \multirow[b]{2}{*}{ 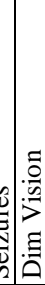 } & & \multirow[b]{2}{*}{ 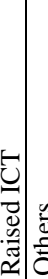 } & & & \multicolumn{3}{|c|}{$\begin{array}{c}\text { Densit } \\
y\end{array}$} & & \multirow[b]{2}{*}{ : } & & \multirow[b]{2}{*}{ 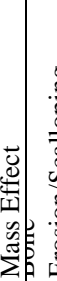 } & \multirow[b]{2}{*}{ 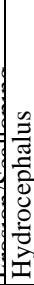 } & $\begin{array}{l}\text { Patt } \\
\text { ern }\end{array}$ & \multicolumn{3}{|c|}{$\begin{array}{c}\text { Enhance } \\
\text { ment }\end{array}$} & \multicolumn{3}{|c|}{$\begin{array}{l}\text { Marg } \\
\text { ins }\end{array}$} & \\
\hline & & & & & & & & & 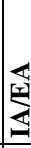 & & 矛 & 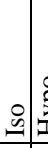 & & & & & & & : & 을 & \begin{tabular}{|c|}
$\mid$ \\
$z$ \\
\\
\end{tabular} & 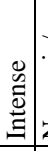 & 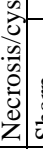 & : & & \\
\hline 1 & \begin{tabular}{|l} 
AROTI \\
MOL
\end{tabular} & $\begin{array}{l}189 \\
729\end{array}$ & \begin{tabular}{l|}
1 \\
6
\end{tabular} & $\mathrm{~F}$ & $\mathrm{~N} / \mathrm{r}$ & $\mathrm{N}$ & 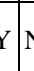 & $\mathrm{N} N$ & $\begin{array}{l}\text { E } \\
\text { A }\end{array}$ & $\begin{array}{l}\text { SELLAR/SUPRA } \\
\text { SELLAR }\end{array}$ & & $\mathrm{Y} \mid \mathrm{N}$ & $\mathrm{N} Y$ & & $\mathrm{~N}$ & $\mathrm{Y}$ & $\mathrm{Y} \mid \mathrm{I}$ & $\mathrm{N} \mid \mathrm{N}$ & $\mathrm{N} \mid \mathrm{Y}$ & $\mathrm{N}$ & $\mathrm{N}$ & $\mathrm{Y} Y$ & Y & Y 1 & $\mathrm{~N}$ & $\begin{array}{l}\text { CRANIOPHARYNGI } \\
\text { OMA }\end{array}$ \\
\hline 2 & \begin{tabular}{|l} 
RAJEN \\
LITIN
\end{tabular} & $\begin{array}{l}257 \\
632\end{array}$ & $\begin{array}{l}1 \\
8\end{array}$ & $\mathrm{M}$ & & $\mathrm{N} \mid \mathrm{N}$ & $\mathrm{N} Y$ & $\mathrm{Y} \mid \mathrm{N}$ & & $\begin{array}{l}\text { PINEAL AND } \\
\text { SELLAR }\end{array}$ & $\mathrm{Y} \mid \mathrm{I}$ & $\mathrm{N} / \mathrm{N}$ & $\mathrm{N} Y$ & & $\mathrm{~N}$ & & $N$ & Y Y & $\mathrm{Y} \mid \mathrm{N}$ & $\mathrm{N}$ & $\mathrm{N}$ & $\mathrm{Y} \mid \mathrm{I}$ & $\mathrm{N}$ & Y 1 & $\mathrm{~N}$ & $\begin{array}{l}\text { PINEAL } \\
\text { GERMINOMA }\end{array}$ \\
\hline $\begin{array}{l}2 \\
1\end{array}$ & $\begin{array}{l}\text { NANDA } \\
\text { GOGOI }\end{array}$ & $\begin{array}{l}268 \\
342\end{array}$ & \begin{tabular}{l|}
1 \\
7
\end{tabular} & $\mathrm{~F}$ & $\mathrm{Y} \mid \mathrm{I}$ & $\mathrm{N} \mid \mathrm{N}$ & & $\mathrm{N} N$ & & $\begin{array}{l}\text { PARASAGGITA } \\
\text { L }\end{array}$ & $\mathrm{N}$ & $\mathrm{Y} \mid \mathrm{N}$ & $\mathrm{N} Y$ & & $\mathrm{Y}$ & $\mathrm{N}$ & $\mathrm{N} / \mathrm{I}$ & $N$ & $\mathrm{Y} \mid \mathrm{N}$ & $\mathrm{N}$ & $\mathrm{Y}$ & $\mathrm{N}$ & $\mathrm{Y} \mid \mathrm{Y}$ & Y & $\mathrm{N}$ & MENINGIOMA \\
\hline $\begin{array}{l}2 \\
2\end{array}$ & ANI TANTI & $\begin{array}{l}321 \\
598\end{array}$ & 7 & $\mathrm{M}$ & & $\mathrm{N} \mid \mathrm{N}$ & $\mathrm{N} / \mathrm{I}$ & $\mathrm{N} / \mathrm{Y}$ & A & PARIET AL & $\mathrm{Y} / \mathrm{I}$ & $\mathrm{N} / \mathrm{N}$ & $\mathrm{N} Y$ & & $\mathrm{~N}$ & $\mathrm{~N}$ & $\mathrm{Y} \mid \mathrm{I}$ & & $\mathrm{N} / \mathrm{Y}$ & $\mathrm{N}$ & $\mathrm{N}$ & $\mathrm{Y} Y$ & $\mathrm{Y}$ & Y & $\mathrm{N}$ & PNET \\
\hline $\begin{array}{l}2 \\
3\end{array}$ & $\begin{array}{l}\text { JASHMIN } \\
\text { BEGUM }\end{array}$ & $\begin{array}{l}269 \\
850\end{array}$ & $\begin{array}{l}1 \\
7\end{array}$ & $\mathrm{~F}$ & $\mathrm{~N} / \mathrm{I}$ & $\mathrm{N} \mid \mathrm{N}$ & $\mathrm{N} Y$ & $\mathrm{Y} \mid \mathrm{N}$ & I & $\begin{array}{l}\text { PERIVENTRICU } \\
\text { LAR }\end{array}$ & $\mathrm{N}$ & $\mathrm{Y} \mid \mathrm{N}$ & $\mathrm{N} Y$ & & $\mathrm{Y}$ & $\mathrm{Y} \mid \mathrm{I}$ & $\mathrm{N} \mid \mathrm{I}$ & & $\mathrm{N} / \mathrm{Y}$ & $\mathrm{N}$ & $\mathrm{N}$ & $\mathrm{Y} \mid \mathrm{P}$ & $\mathrm{N}$ & $\mathrm{Y} \mid \mathrm{I}$ & $\mathrm{N}$ & EPENDYMOMA \\
\hline 2 & $\begin{array}{l}\text { DIANA } \\
\text { NGUTE }\end{array}$ & $\begin{array}{l}276 \\
284\end{array}$ & 2 & $\mathrm{M}$ & & $\mathrm{N} \mid \mathrm{N}$ & $\mathrm{N} Y$ & $\mathrm{Y} \mid \mathrm{N}$ & & $\begin{array}{l}\text { LATERAL } \\
\text { VENTRICLE }\end{array}$ & $\mathrm{Y} \mid \mathrm{I}$ & $\mathrm{N} / \mathrm{N}$ & $\mathrm{N} Y$ & & $\mathrm{Y}$ & $\mathrm{N} / \mathrm{I}$ & $\mathrm{N}$ & $\mathrm{Y} \mid \mathrm{N}$ & $\mathrm{N} Y$ & $\mathrm{~N}$ & $\mathrm{~N}$ & $\mathrm{Y} Y$ & $\mathrm{Y}$ & Y 1 & $\mathrm{~N}$ & $\begin{array}{l}\text { CHOROID PLEXUS } \\
\text { PAPILLOMA }\end{array}$ \\
\hline $\begin{array}{l}2 \\
5\end{array}$ & $\begin{array}{l}\text { THANESH } \\
\text { WAR }\end{array}$ & $\begin{array}{l}183 \\
733\end{array}$ & 8 & $\mathrm{M}$ & & $\mathrm{N} \mid \mathrm{N}$ & $\mathrm{N} / \mathrm{N}$ & $\mathrm{N} / \mathrm{N}$ & $\begin{array}{l}\mathrm{I} \\
\mathrm{A}\end{array}$ & $\begin{array}{l}\text { BASAL } \\
\text { GANGLIA }\end{array}$ & $\mathrm{N}$ & $\mathrm{N} Y$ & $\mathrm{Y} \mid \mathrm{N}$ & & $\mathrm{N}$ & $\mathrm{N}$ & $\mathrm{N} / \mathrm{I}$ & $\mathrm{N}$ & $\mathrm{Y} \mid \mathrm{N}$ & $\mathrm{Y}$ & $\mathrm{N}$ & $\mathrm{N}$ & $\mathrm{Y}$ & Y & $\mathrm{N}$ & $\begin{array}{l}\text { PILOCYTIC } \\
\text { ASTROCYTOMA }\end{array}$ \\
\hline $\begin{array}{l}2 \\
6\end{array}$ & $\begin{array}{l}\text { MUKESH } \\
\text { SAIKIA }\end{array}$ & $\begin{array}{l}243 \\
471\end{array}$ & 9 & $\mathrm{M}$ & & $\mathrm{N} \mid \mathrm{r}$ & $\mathrm{N} / \mathrm{h}$ & $\mathrm{N} Y$ & $\begin{array}{l}\mathrm{I} \\
\mathrm{A}\end{array}$ & $\begin{array}{l}\text { PERIVENTRICU } \\
\text { LAR }\end{array}$ & $\mathrm{N}$ & $\mathrm{N} / \mathrm{Y}$ & $\mathrm{Y} \mid \mathrm{N}$ & & $\mathrm{Y}$ & $\mathrm{Y} \mid \mathrm{I}$ & $\mathrm{N} \mid \mathrm{I}$ & $\mathrm{N}$ & $\mathrm{Y} \mid \mathrm{N}$ & $\mathrm{N}$ & $\mathrm{Y}$ & $\mathrm{N}$ & $\mathrm{Y}$ & Y & $\mathrm{N}$ & $\begin{array}{l}\text { PILOCYTIC } \\
\text { ASTROCYTOMA }\end{array}$ \\
\hline $\begin{array}{l}2 \\
7\end{array}$ & $\begin{array}{l}\text { ALI } \\
\text { AHMED }\end{array}$ & $\begin{array}{l}287 \\
329\end{array}$ & $\begin{array}{l}1 \\
3\end{array}$ & $\mathrm{M}$ & $\mathrm{N}$ & $\mathrm{Y} \mid \mathrm{N}$ & $\mathrm{N} / \mathrm{N}$ & $\mathrm{N} / \mathrm{N}$ & I & TEMPORAL & $\mathrm{N}$ & $\mathrm{N}$ & Y $\mathrm{Y}$ & & $\mathrm{Y}$ & $\mathrm{N} / \mathrm{I}$ & $N \mid \mathrm{I}$ & & $\mathrm{N} / \mathrm{Y}$ & Y & $\mathrm{N}$ & $\mathrm{N}$ & $\mathrm{Y}$ & $\mathrm{Y} \mid \mathrm{I}$ & $\mathrm{N}$ & GANGLIOGLIOMA \\
\hline $\begin{array}{l}2 \\
8\end{array}$ & \begin{tabular}{|l} 
RAHUL \\
JAIN
\end{tabular} & $\begin{array}{l}376 \\
483\end{array}$ & 7 & $\mathrm{M}$ & $\mathrm{N} / \mathrm{N}$ & $\mathrm{N} \mid \mathrm{N}$ & & $\mathrm{Y} \mid \mathrm{N}$ & I & $\begin{array}{l}\text { TEMPOROPARI } \\
\text { ETAL }\end{array}$ & $\mathrm{Y} \mid \mathrm{I}$ & $\mathrm{N} / \mathrm{N}$ & $\mathrm{N} Y$ & & $\mathrm{Y}$ & $\mathrm{Y}$ & $N \mid \mathrm{I}$ & & $\mathrm{N} / \mathrm{Y}$ & $\mathrm{N}$ & $\mathrm{N}$ & $\mathrm{Y} Y$ & $\mathrm{Y}$ & $\mathrm{Y} \mid \mathrm{I}$ & $\mathrm{N}$ & PNET \\
\hline $\begin{array}{l}2 \\
9\end{array}$ & $\begin{array}{l}\text { AJIT } \\
\text { CHANDRA }\end{array}$ & $\begin{array}{l}400 \\
312\end{array}$ & $\begin{array}{l}1 \\
4\end{array}$ & $\mathrm{M}$ & $\mathrm{N} \mid \mathrm{I}$ & $\mathrm{N} \mid \mathrm{N}$ & $\mathrm{N} Y$ & $\mathrm{Y} \mid \mathrm{N}$ & I & FRONTAL & $\mathrm{N}$ & $\mathrm{N}$ & $\mathrm{Y} \mid \mathrm{N}$ & & $\mathrm{Y}$ & $\mathrm{Y}$ & $\mathrm{N}$ & $\mathrm{Y} \mid \mathrm{I}$ & $\mathrm{N} Y$ & $\mathrm{~N}$ & $\mathrm{~N}$ & $\mathrm{Y} Y$ & $\mathrm{Y}$ & $\mathrm{Y}$ & Y & $\begin{array}{l}\text { ANAPLASTIC } \\
\text { ASTROCYTOMA }\end{array}$ \\
\hline $\begin{array}{l}3 \\
0\end{array}$ & PRIY ASHRI & $\begin{array}{l}412 \\
238\end{array}$ & $\begin{array}{l}1 \\
6\end{array}$ & $\mathrm{~F}$ & $\mathrm{~N} / \mathrm{r}$ & $\mathrm{N} \mid \mathrm{N}$ & $\mathrm{N} Y$ & $\mathrm{Y} \mid \mathrm{N}$ & & $\begin{array}{l}\text { PERIVENTRICU } \\
\text { LAR }\end{array}$ & $\mathrm{N}$ & $\mathrm{Y} \mid \mathrm{I}$ & $\mathrm{N} Y$ & & $\mathrm{Y}$ & $\mathrm{Y} \mid \mathrm{I}$ & $\mathrm{N} \mid \mathrm{I}$ & $\mathrm{N} / \mathrm{I}$ & $\mathrm{N} / \mathrm{Y}$ & $\mathrm{N}$ & $\mathrm{Y}$ & $\mathrm{N}$ & Y 1 & $\mathrm{~N}$ & Y & $\begin{array}{l}\text { ANAPLASTIC } \\
\text { ASTROCYTOMA }\end{array}$ \\
\hline $\begin{array}{l}3 \\
1 \\
\end{array}$ & $\begin{array}{l}\text { PINTU } \\
\text { NEOG }\end{array}$ & $\begin{array}{l}356 \\
218 \\
\end{array}$ & 8 & $\mathrm{M}$ & $\mathrm{N} / \mathrm{I}$ & $\mathrm{N} \mid \mathrm{r}$ & $\mathrm{N} / \mathrm{N}$ & $\mathrm{N} Y$ & & $\begin{array}{l}\text { BASAL } \\
\text { GANGLIA }\end{array}$ & $\mathrm{Y}$ & $\mathrm{N} / \mathrm{N}$ & $\mathrm{N} N$ & & $\mathrm{Y}$ & $\mathrm{Y} \mid \mathrm{I}$ & $\mathrm{N} \mid \mathrm{I}$ & $\mathrm{N} / \mathrm{I}$ & $\mathrm{N} Y \mathrm{Y}$ & $\mathrm{N}$ & $\mathrm{Y}$ & $\mathrm{N}$ & $\mathrm{Y} \mid \mathrm{I}$ & $\mathrm{N}$ & Y & GBM \\
\hline $\begin{array}{l}3 \\
2\end{array}$ & $\begin{array}{l}\text { BHAGYAL } \\
\text { ATHA }\end{array}$ & $\begin{array}{l}179 \\
054\end{array}$ & $\begin{array}{l}1 \\
7\end{array}$ & $\mathrm{~F}$ & $\mathrm{~N} / \mathrm{I}$ & $\mathrm{N} \mid \mathrm{N}$ & $\mathrm{N}$ & $\mathrm{Y} \mid \mathrm{N}$ & $\begin{array}{l}\text { I } \\
\text { A }\end{array}$ & $\begin{array}{l}\text { FRONTOPARIE } \\
\text { TAL }\end{array}$ & $\mathrm{N}$ & $\mathrm{Y} \mid \mathrm{I}$ & $\mathrm{N} N$ & & $\mathrm{Y}$ & $\mathrm{Y} \mid \mathrm{I}$ & $\mathrm{N}$ & $\mathrm{Y} \mid \mathrm{I}$ & $\mathrm{N} / \mathrm{Y}$ & $\mathrm{Y}$ & $\mathrm{N}$ & $\mathrm{N}$ & $\mathrm{Y} \mid \mathrm{I}$ & $\mathrm{N}$ & Y & GBM \\
\hline $\begin{array}{l}3 \\
3\end{array}$ & $\begin{array}{l}\text { SANGITA } \\
\text { SAIKIA }\end{array}$ & $\begin{array}{l}301 \\
298\end{array}$ & $\begin{array}{l}1 \\
2\end{array}$ & $\mathrm{~F}$ & $\mathrm{~N} \mid \mathrm{I}$ & $\mathrm{N}$ & $\mathrm{Y} \mid \mathrm{I}$ & $\mathrm{N} N$ & & OPTIC CHIASM & $\mathrm{N}$ & $\mathrm{N}$ & $\mathrm{Y} N$ & & $\mathrm{~N}$ & $\mathrm{~N}$ & $\mathrm{Y} \mid \mathrm{I}$ & $\mathrm{N}$ & $\mathrm{Y} \mid \mathrm{N}$ & $\mathrm{Y}$ & $\mathrm{N}$ & $\mathrm{N} \mid \mathrm{I}$ & $\mathrm{N}$ & Y 1 & $\mathrm{~N}$ & $\begin{array}{l}\text { OPTIC PATHWAY } \\
\text { GLIOMA }\end{array}$ \\
\hline $\begin{array}{l}3 \\
4\end{array}$ & BHIJITESH & $\begin{array}{l}287 \\
652\end{array}$ & 1 & $\mathrm{M}$ & $\mathrm{N}$ & $\mathrm{N} \mid \mathrm{N}$ & $\mathrm{N}$ & $\mathrm{Y} \mid \mathrm{N}$ & $\begin{array}{l}\text { I } \\
\text { A }\end{array}$ & $\begin{array}{l}\text { FRONTOTEMPO } \\
\text { RAL }\end{array}$ & $\mathrm{Y}$ & $\mathrm{N}$ & $\mathrm{N} / \mathrm{N}$ & & $\mathrm{Y}$ & $\mathrm{Y}$ & $\mathrm{Y}$ & $\mathrm{Y}$ & $\begin{array}{l}\mathrm{Y} \\
\mathrm{N}\end{array}$ & $\mathrm{N}$ & $\mathrm{N}$ & $\mathrm{Y}$ & $\mathrm{Y}$ & Y & $\mathrm{N}$ & DIG \\
\hline $\begin{array}{l}3 \\
5\end{array}$ & NAREN G & $\begin{array}{l}295 \\
682 \\
\end{array}$ & $\begin{array}{l}1 \\
5 \\
\end{array}$ & $\mathrm{M}$ & $\mathrm{N}$ & $\mathrm{Y} \mid \mathrm{N}$ & $\mathrm{N} / \mathrm{I}$ & $\mathrm{N} / \mathrm{N}$ & & $\begin{array}{l}\text { FRONTAL \& } \\
\text { VENTRICLE }\end{array}$ & $\mathrm{N}$ & $\mathrm{N}$ & $\mathrm{Y} Y$ & & $\mathrm{~N}$ & $\mathrm{~N}$ & $N \mid I$ & $\mathrm{~N} \mid \mathrm{I}$ & $N \mid Y$ & $\mathrm{Y}$ & $\mathrm{N}$ & $\mathrm{N}$ & $\mathrm{Y}$ & $\mathrm{Y}$ & $\mathrm{N}$ & $\begin{array}{l}\text { OLIGODENDROGLI } \\
\text { OMA }\end{array}$ \\
\hline $\begin{array}{l}3 \\
6\end{array}$ & \begin{tabular}{|l|} 
DIPTI \\
ORANG
\end{tabular} & $\begin{array}{l}312 \\
785\end{array}$ & $\begin{array}{l}1 \\
7\end{array}$ & $\mathrm{~F}$ & $\mathrm{~N} / \mathrm{N}$ & $\mathrm{N} / \mathrm{N}$ & $\mathrm{N}$ & $Y$ & & $\begin{array}{l}\text { LATERAL } \\
\text { VENTRICLE }\end{array}$ & $\mathrm{N}$ & $\mathrm{Y} \mid \mathrm{I}$ & $\mathrm{N} Y$ & & & $\mathrm{~N}$ & $\mathrm{~N}$ & & Y & $\mathrm{N}$ & $\mathrm{Y}$ & $\mathrm{N}$ & $\mathbf{Y}$ & $\mathrm{Y}$ & & $\begin{array}{l}\text { CENTRAL } \\
\text { NEUROCYTOMA }\end{array}$ \\
\hline
\end{tabular}




\section{Representative cases}

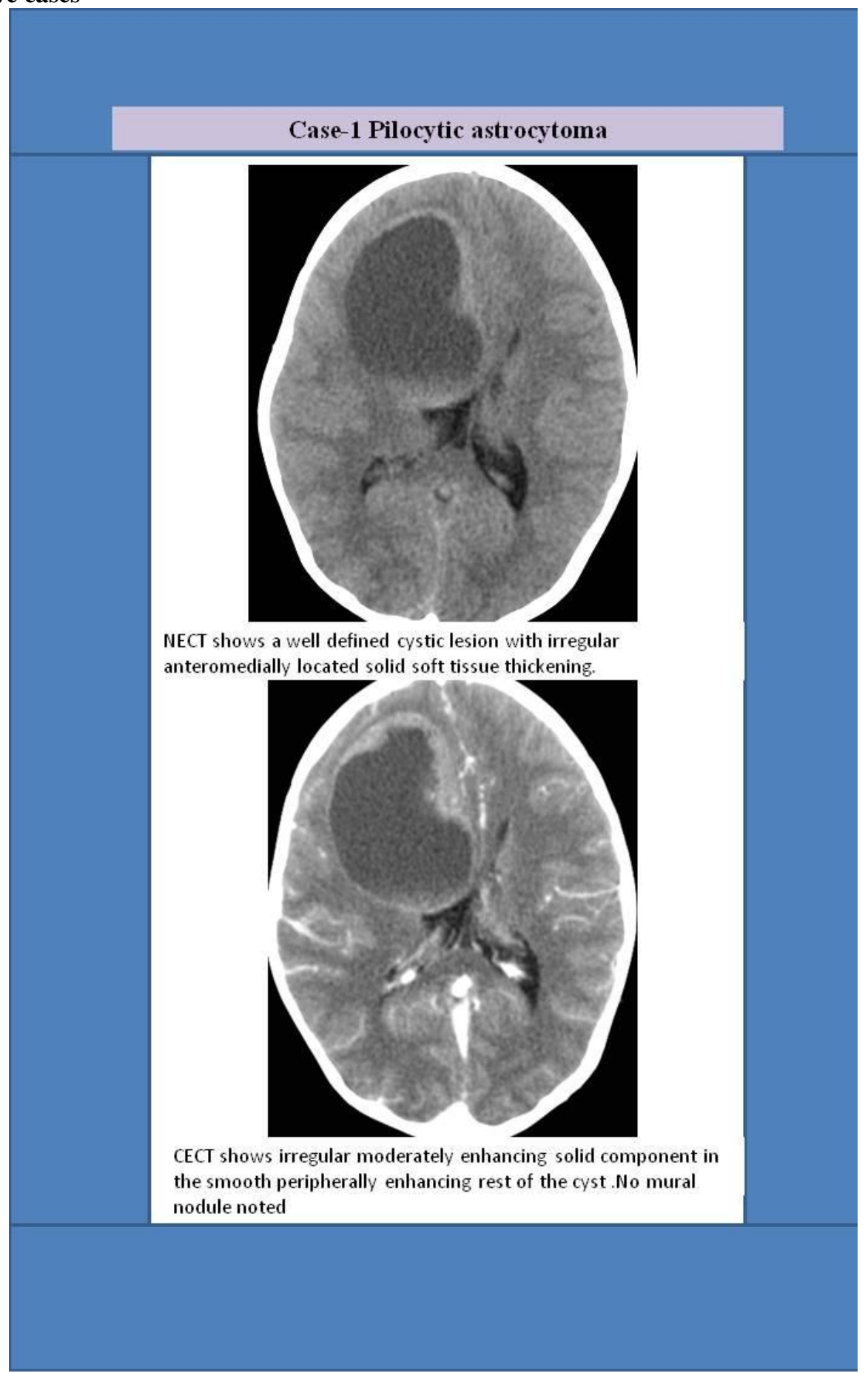




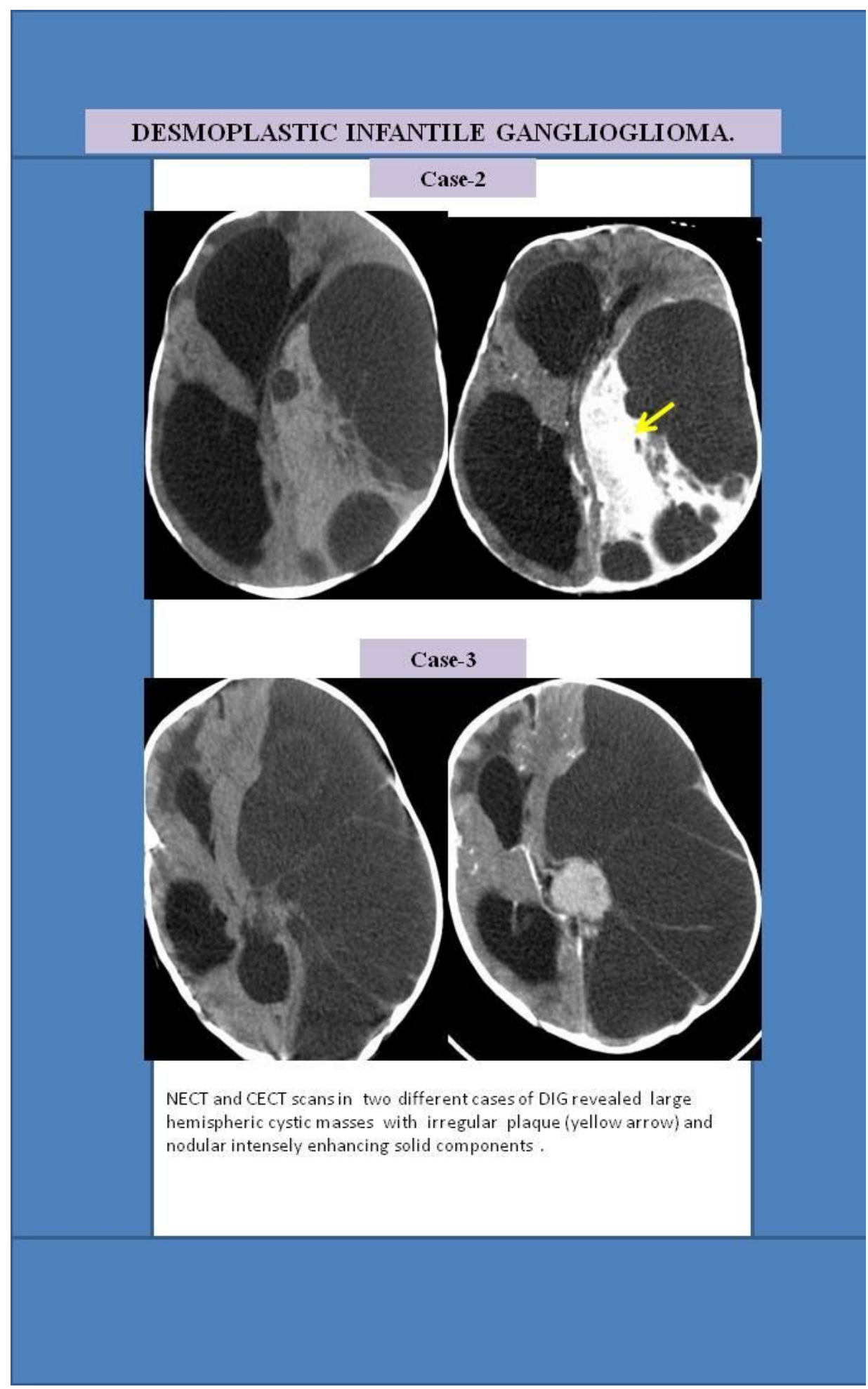




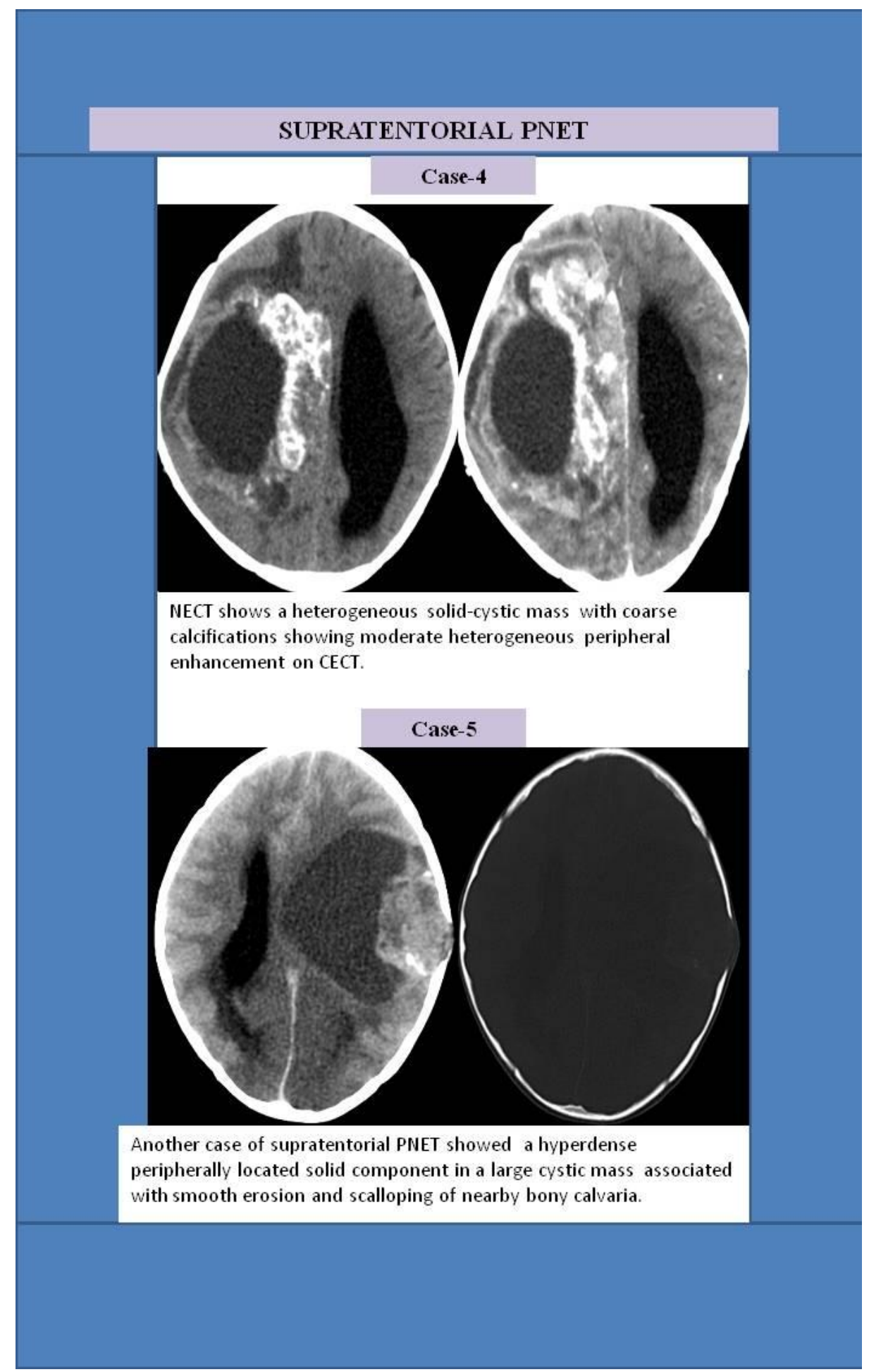




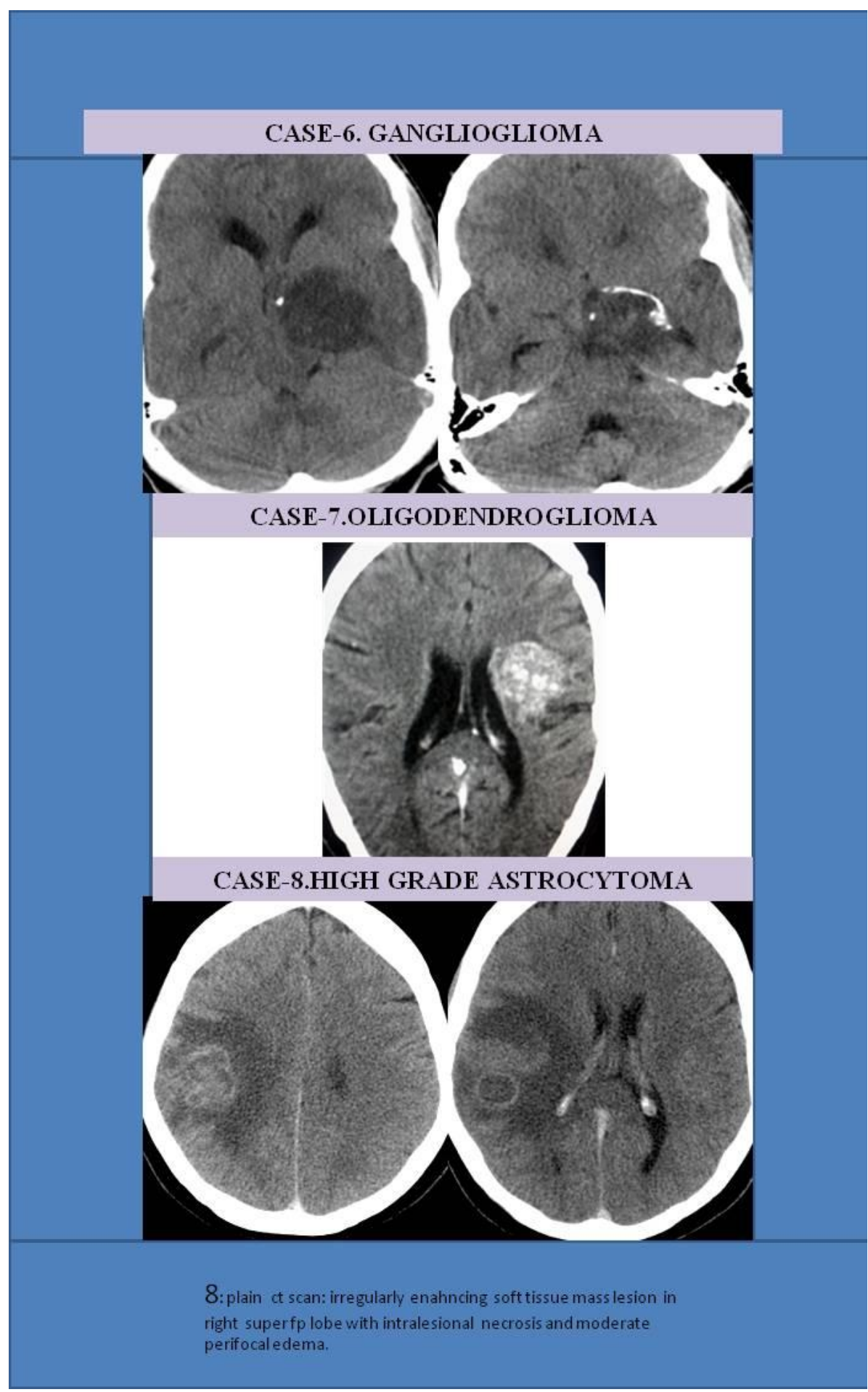




\section{References}

[1]. Therese A. Dolecek, Jennifer M. Propp, Nancy E. Stroup, and Carol Kruchko. CBTRUS Statistical Report: Primary Brain and Central Nervous System Tumors Diagnosed in the United States in 2005 - 2009. Neuro-Oncology14:v1 - v49, 2012.

[2]. Kumar R. Scenario of pediatric CNS tumors in India. JK Sci. 2006; 8: 190-2.

[3]. Haque MZ, Karim ME, Al-Azad S, Mahmood-uz jahan. Role of computed tomography in the evaluation of pediatric brain tumor. Bangladesh Med Res Counc Bull. 2010; 36: 89-92.

[4]. Higano S, Takahashi S, Kurihara N et al Supratentorial primary intra-axial tumors in children. MR and CT evaluation. Acta Radiol 1997; 38:945-952

[5]. Brant-Zawdzki M, Badami JP, Mills CM. Primary intracranial tumor imaging: A comparison of magnetic resonance and CT. Radiology 1984; 150: 435-440.

[6]. Khalid Khan, Ahmed Nadeem Qureshi, Phool Bibi, Muhammad Jehanzeb. Accuracy of computerised tomography in diagnosis of brain tumours in children. J Ayub Med Coll Abbottabad 2009; 21(2).42-44.

[7]. Sadler T.W, Langman's. Langman's Medical embryology", 9th edition, USA: Williams and Wilkins 2004:433-483

[8]. Snell RS, editor. "Clincal neuroanatomy for medical students", 7th edition, Baltimore USA: Lippincott Williams and Wilkins, 2010. 251-521

[9]. Haaga, John R. CT and MRI anatomy of the whole body. CT and MRI of the whole body, 5th edition, 2009. Mosby, 3-145.

[10]. A.James Barkovich 4th ed, Pediatric neuroimaging. 2005

[11]. Kamil Zelenak, Cisarikova Viera and Polacek Hubert. Clinical Management and Evolving Novel Therapeutic Strategies for Patients with Brain Tumors. Radiology Imaging Techniques of Brain Tumours. Chapter 4: 77-105

[12]. Leeds NE, Kieffer SA. Evolution of Diagnostic Neuroradiology from 1904 to 1999. Radiology 2000;217(2):309-318.

[13]. Seeram E. Computed Tomography: Physical principles, clinical applications and quality control, 2nd edition Philadelphia, USA: W.B. Saunders. 2001: 7-12.

[14]. Baker H.L., Wayne Houser and Keith Campbel. National Cancer Institute study: Evaluation of Computed Tomography in the Diagnosis of Intracranial Neoplasms. Radiology 1980; 136:91-96.

[15]. Segall HD, Destians, Nelson MD et al. CT and MR imaging in malignant gliomas. In: Apuzzo MLJ (ed). Malignant Cerebral glioma. Park Ridge, IL. American Association of Neurologic Surgeons 1990: 63-78.

[16]. Richard SB Neuroradiology of brain Tumors. Neurol Clin 1995; 13(4): 723-756.

[17]. Sutton David, Brain Kendall, John Stevens. "Intracranial lesions". Chapter 58 (1) In; David Sutton, editor, Radiology and imaging, 7th edition, New York: Churchill living stone. 2003; 2:1767-1819.

[18]. Taghipour Zahir SH, Rezaei Sadrabadi M, Dehghani F. Evaluation of diagnostic value of ct scan and mri in brain tumors and comparison with biopsy Iranian Journal of Pediatric Hematology Oncology 2011;1(4):121-125

[19]. Clinical, imaging and Laboratory diagnosis of brain tumors. In: Kaye A, Laws E, eds. Brain Tumors. New York". Churchill Livingstone 1995; 219-220.

[20]. Majors Carlos, Garcia Corcurella, Carlos Aguilera, Sylvia Coll and Luis C. Pons. Intraventricular meningiomas . MR imaging and MR spectroscopic findings in two cases". AJNR 1999; 20: 882-885.

[21]. Kaye A.H., Edward R, Laws M. "Brain tumours an encyclopedic approach", 1" edition, Edinberg: Churchill Livingstone, 1995.

[22]. Jager R, Saunders D, Murray A and Stevens. "The skull and brain: methods of examination and anatomy". Chapter-97 In: R.G. Grainger., DJ Allison, A Adam, AK Dixon, edts, Diagnostic Radiology: A text book of medical imaging, 4th edition, Vol.3, London: Churchill Livingstone, 2001: 2299-2323.

[23]. Louis, D. N, Ohgaki.H., Wiestler. O. D., Cavenee, W. K., Burger, P. C., Jouvet, A., \& Kleihues, P. The 2007 WHO classification of tumours of the central nervous system. Acta neuropathologica, 2007; 114(2): 97-109.

[24]. Louis DN, Ohgaki H, Wiestler OD, Cavenee WK (eds) (2007) WHO Classification of tumours of the central nervous system. IARC, Lyon.

[25]. Nayil K, Makhdoomi R, Ramzan A, Zahoor S, Rasool M, Wani A, Dhar A, Mubeen B, Singh S, Bhat R, Kirmani A: Childhood tumors of the brain: demographic pattern over a ten-year period in the Kashmir valley. Pediatr Neurosurg 2011;47:31-37.

[26]. Zhou D, Zhang Y, Liu H, Luo S, Luo L, Dai K. Epidemiology of Nervous System Tumors in Children: A Survey of 1,485 Cases in Beijing Tiantan Hospital from 2001 to 2005. Pediatr Neurosurg 2008;44:97-103

[27]. Nasir S, Jamila B, Khaleeq S: A retrospective study of primary brain tumors in children under 14 years of age at PIMS, Islamabad. Asian Pac J Cancer Prev 2010;11:1225-1227.

[28]. Rosemberg S, \& Fujiwara D. Epidemiology of pediatric tumors of the nervous system according to the WHO 2000 classification: a report of 1,195 cases from a single institution. Child's Nervous System 2005; 21(11): 940-944.

[29]. Naseem Ahmed, Yasmin Bhurgri, Saleem Sadiq, Kazi A Shakoor . Pediatric Brain Tumours at a Tertiary Care Hospital in Karachi. Asian Pacific J Cancer Prev 2007;8:399-404.

[30]. Jain A, Sharma MC, Suri V, Kale SS, Mahapatra AK, Tatke M, et al. Spectrum of pediatric brain tumors in India: A multiinstitutional study. Neurol India 2011; 59:208-11.

[31]. Md K Faheem N, Jyothi V, B Syama SR. Pediatric Tumors of Central Nervous System (CNS) - An Epidemiopathologic Research Study. Int J Med Health Sci 2012;1(3):73-82

[32]. Harmouch, A, Taleb, M, Lasseini, A, Maher, M, \& Sefiani, S. Epidemiology of pediatric primary tumors of the nervous system: A retrospective study of 633 cases from a single Moroccan institution. Neurochirurgie 2012; 58(1):14-18.

[33]. Heike E, Daldrup-Link, Charles A. Gooding: Essentials of pediatric radiology: a multimodality approach. 2010, 186-187

[34]. Nishio SH, Takeshita I, Fuji I, Fukui M. Supratentorial astrocytic tumours of childhood: a clinicopathologic study of 41 cases. Acta Neurochir (Wien) 1989;101:3-8.

[35]. Pederson H, Gjerris F, Klinken L. Computed tomography of benign supratentorial astrocytomas of infancy and childhood. Neuroradiology 1981;21:87 -91.

[36]. D. Afra, W. Muller, F. Slowik, R. Firsching. Supratentorial lobar pilocytic astrocytomas: Report of 45 operated cases, inclu ding 9 recurrences Acta Neurochirurgica 1986; 81(3-4):90-93.

[37]. Lee YY, Van Tassel P, Bruner JM, Moser RP, Share JC. Juvenile pilocytic astrocytomas: CT and MR characteristics. Am J Roentgenol. 1989 Jun;152(6):1263-70

[38]. Niculescu C. E, Stanescu L, Popescu M, \& Niculescu, D. Supratentorial pilocytic astrocytoma in children . Romanian Journal of Morphology and Embryology 2010, 51(3):577-580.

[39]. Crespo-Rodriguez AM, Smirniotopoulos JG, Rushing EJ. MR and CT imaging of 24 pleomorphic xanthoastrocytomas (PXA) and a review of the literature. Neuroradiology 2007; 49:307-15.

[40]. Douis, H, Andronikou, S, \& von Bezing, H. Pleomorphic xanthoastrocytoma: Case series with radiologic-pathological correlation and review of the literature. European Journal of Radiology Extra 2008; 68(1): 5-8.

DOI: 10.9790/0853-1312687108 www.iosrjournals.org $107 \mid$ Page 
[41]. Crino PB, Nathanson KL, Henske EP. The tuberous sclerosis complex. New England Journal of Medicine 2006; 355:1345-56.

[42]. Moran V, O Keeffe F. Giant cell astrocytoma in tuberous sclerosis: computed tomographic findings. Clin Radiol. 1986 Nov; 37(6):543-5.

[43]. R Nabbout, M Santos, Y Rolland, O Delalande, O Dulac, C Chiron. Early diagnosis of subependymal giant cell astrocytoma in children with tuberous sclerosis. J Neurol Neurosurg Psychiatry 1999;66:370-375

[44]. Clarke, M. J., Foy, A. B., Wetjen, N., \& Raffel, C. Imaging characteristics and growth of subependymal giant cell astrocytomas. Neurosurgical focus 2006;20(1):1-4.

[45]. Adriaensen M. E. A. P. M., Schaefer -Prokop, C. M., Stijnen, T., Duyndam, D. A., Zonnenberg, B. A., \& Prokop, M. Prevalence of subependymal giant cell tumors in patients with tuberous sclerosis and a review of the literature. European Journal of Neurology 2009;16(6):691-696.

[46]. Fangusaro, J. (2012). Pediatric high grade glioma: a review and update on tumor clinical characteristics and biology. Frontiers in oncology; 2/ Pediatric Oncology 2012; 2(105): 1-10 